\title{
ЛЮДИКОВИЙ РААХЕ-ЛАДОЖСКОЙ ЗОНЫ ФЕННОСКАНДИНАВСКОГО ЩИТА - ИЗОТОПНО- ГЕОХИМИЧЕСКОЙ СОСТАВ И ГЕОДИНАМИЧЕСКАЯ ПРИРОДА
}

Вревский А. Б.

\begin{abstract}
Аннотация
А.Б. ВРеВСКИЙ «ЛЮДИКОВИЙ РААХЕ-ЛАДОЖСКОЙ ЗОНЫ ФЕННОСКАНДИНАВСКОГО ЩИТА - ИЗОТОПНО-ГЕОХИМИЧЕСКОЙ СОСТАВ И ГЕОДИНАМИЧЕСКАЯ ПРИРОДА»

В северном Приладожье в юго-восточной части Раахе-Ладожской зоны сочленения эпиархейского Фенно-Карельского кратона и раннепротерозойской Свекофеннской провинции для определения возраста пород сортавальской серии и характера ее соотношения с гранитоидами куполов, возраста источников области сноса и оценки времени проявления метаморфических процессов было проведено изучение изотопного состава $\mathrm{Nd}$, геохимическое и изотопно-геохронологическое исследования акцессорных цирконов из гранито-гнейсов Кирьявалахтинского выступа, базальных граувакк нижней толщи и трахитов средней толщи сортавальской серии, а также, секущих вулканогенно-осадочные толщи сортавальской серии, даек плагио- и диорит-порфиров.
\end{abstract}

На основании полученных новых изотопно-геохимических данных для гранитоидов Киръявалахтинского выступа установлен их неоархейский возраст $2695 \pm 13$ млн. лет и ювенильная природа ( $\varepsilon \mathrm{NdT}=+1.5)$. Гранитоиды испытали тектоно-метаморфические преобразования (реоморфизм) раннепротерозойского (сумийского) времени (2.45-2.50 млрд. лет), запечатленные в $\mathrm{U}-\mathrm{Th}-\mathrm{Pb}$ изотопной системе оболочек древних ядер кристаллов циркона.

Заложение вулканогенно-осадочного комплекса сортавальской серии происходило на гетерогенной и полихронной (3.1 -2.46 млрд. лет) континентальной коре Фенно-Карельского эпиархейского кратона. Исследование U-Th-Pb возраста детритовых цирконов из вулканомиктовых граувакк питкярантской свиты позволили принять с учетом ошибок определения возраста кластогенных цирконов минимальные конкордантные значения в интервале 1940- 1990 млн лет в качестве верхнего возрастного ограничения терригенных пород, что согласуется с оценкой максимального возраста пород сортавальской серии в целом по U-Th-Pb (SIMS) возрасту 1922士11 млн. лет диоритов “Терваоя”.

Предложена тектоническая модель, согласно которой ко времени начала свекофеннской коллизии континент-островная дуга, субдукции и формирования бимодальных вулкано-плутонических комплексов юных островных дуг Пюхисалми и кислых вулканитов сланцевого пояса Саво (19201890 млн. лет), в перикратонной части Фенно-Карельского эпиархейского кратона уже произошло накопление вулканогенно-осадочного комплекса сортавальской серии, его метаморфизм, эрозия и несогласное перекрытие турбидитами ладожской серии.

15 рисунков, 8 таблиц

Ключевые слова: Фенноскандинавский щит, Раахе-Ладожская зона, Северное Приладожье, людиковий, сортавальская сери, Кирьявалахтинский выступ, U-Th- Pb геохронология, Sm-Nd изотопия, геохимия редкоземельных элементов. 
A.B. Vrevskii. "Ludicovian of the Raahe-Ladoga zone, Fennoscandian Shield -geochemical and isotopic composition and geodynamic nature".

Based on the new isotopic-geochemical data obtained for the granitoids of the Kirjavolakhta protrusion (dome) (the north Priladozhye, the southeastern part of Raahe-Ladoga connection of the Fenno-Karelian epi-arhaean craton and the early proterozoic Svekofennian province), their neo-Archaean U-Th-Pb zircon age $(2695 \pm 13 \mathrm{Ma}$.) and juvenile nature $(\varepsilon N d T=+1.5)$ was established. The granites have experienced tectonic-metamorphic transformations (reomorphism) in Early Proterozoic (Sumian) time (2.45-2.50 b. a.).Deposition of the Sortavala volcano-sedimentary complex took place on the heterogeneous and polychronic (3.1 -2.46 Ba.) continental crust of the Fenno-Karelian epi-arhaean craton. The age of detrital zircons from the volcanoclastic layers of the Pitkyaranta suite allowed accepting the youngest value of $U$ Th- $\mathrm{Pb}$ (SIMS) age (1958 $\pm 17 \mathrm{Ma})$ as the upper depositional age limit of the basal metasedimentary unites. This age corresponding with the maximum age of the basal metasediments of the Sortavala group, baized on the $1922 \pm 11$ Ma age of the ”Tervaoya” diorite, which intrude them.

We propose a tectonic model where the formation of the Sortavala volcano-sedimentary complex, its metamorphism, erosion and overlaying by the tourbidites of the Ladoga series preceded the svecofennian initial continent-arc collision, formation of bimodal volcano-plutonic complexes of the young island arcs of Puhisalmi, the acid volcanics of the Savo schis belt (1920-1890 Ma).

15 pic., 8 tabl.

Keywords: Fennoscandian Shield, Raahe-Ladoga zone, north Priladozhye, ludicovian, Kirjavolakhta protrusion (dome), Sortavala Group, Sm-Nd isotopes, geochemistry of the rare earth elements.

\section{Ключевые слова:}

Фенноскандинавский щит, Раахе-Ладожская зона, Северное Приладожье, людиковий, сортавальская сери, Кирьявалахтинский выступ, U-Th- Pb геохронология, Sm-Nd изотопия, геохимия редкоземельных элементов 


\title{
УДК 550.93:551.72(470.22) \\ ЛЮДИКОВИЙ РААХЕ-ЛАДОЖСКОЙ ЗОНЫ ФЕННОСКАНДИНАВСКОГО ЩИТА - ИЗОТОПНО-ГЕОХИМИЧЕСКОЙ СОСТАВ И ГЕОДИНАМИЧЕСКАЯ ПРИРОДА
}

\author{
А.Б. Вревский \\ Институт геологии и геохронологии докембрия РАН \\ 199034, Санкт-Петербург, наб. Макарова, 2 \\ e-mail: avrevsky@mail.ru
}

\section{ВВЕДЕНИЕ}

В тектоническом строении Фенноскандинавского щита северное Приладожье представляет собой юго-восточную часть Раахе-Ладожской зоны сочленения эпиархейского Фенно-Карельского кратона и раннепротерозойской Свекофеннской провинции (Рис. 1). Геологическое своеобразие северного Приладожья определяется структурно-тектоническим сочетанием изолированных выступов гранито-гнейсовых ареалов (т.н. “окаймленных гранито-гнейсовых куполов”) и вулканогенно-осадочных и терригенно-флишоидных образований карелид (рис. 1). Эти супракрустальные образования на территории северного Приладожья представлены преимущественно палеопротерозойскими ассоциациями пород нижнекарельского комплекса (2300-1650 млн. лет). Здесь выделяется ятулийский (2300 - 2100 млн. лет) (кварциты, кварцитопесчаники, алевролиты, алевропелиты с горизонтами доломитов и основных метавулканитов), людиковийский (2100 - 1950 млн. лет) (вулканогенно-осадочные толщи сортавальской и питкярантской серий) и калевийский (1950 - 1920 млн. лет) (метатурбидиты ладожской серии) надгоризонты [Семихатов, 1993; Общая стратиграфическая ...., 2002; Общая........, 2013].

Многие проблемы стратиграфического расчленения и корреляции разрезов палеопротерозойских вулканогенно-осадочных комплексов Фенноскандинавского щита, в том числе и выделение людиковийских образований в северном Приладожье, традиционно решались с помощью литолого-стратиграфических методов [Светов, Свириденко, 1992; Светов и др.,1990]. Возможности этих методов для выделения преимущественно вулканогенных образований людиковийского надгоризонта, основанных на корреляции общего набора пород, фациальной принадлежности, закономерностях эволюции минерального и геохимического составов, имеют ряд важных ограничений. Прежде всего, такие ограничения связаны с большими вариациями этих признаков в пределах одной тектонической структуры в зависимости от их положения относительно палеовулканических центров. В региональном плане такая неоднородность тектонического и, соответственно, литолого-формационного строения северного Приладожья и Раахе-Ладожской зоны в целом, выражена в различиях интенсивности проявления, литолого-фациального состава и уровня эрозионного среза лавово-вулканокластических полей извержений, что вызывает естественные трудности для разработки даже идеализированного унифицированного разреза нижнего Карелия в северном Приладожье. 
Отдельной проблемой геологии северного Приладожья, принципиально важной для понимания геодинамики корообразующих процессов в протерозое этой части Фенноскандинавского щита, является установление характера соотношений в пространстве и во времени людиковийских вулканогенно-осадочных комплексов с гранитоидами купольных структур.

Породы нижнекарельского комплекса, смятые в узкие синклинальные и изоклинальные складки, развиты в виде узких полос, конформно окаймляющие куполовидные структуры гранито-гнейсов. В северном Приладожье установлено около двух десятков куполовидных структур размером от 0.5 до $150 \mathrm{kм}^{2}$, которые сгруппированы в двух зонах - в восточной (Питкярантская зона) и западной (Сортавальская зона), в последней наиболее крупным является Кирьявалахтинский купол (рис. 1).

Несмотря на длительную историю геологического изучения, начиная с работ И. Седерхольма [Sederholm, 1934] и П. Эскола [Eskola, 1967], до настоящего времени не существует аргументированных представлений о генезисе гранито-гнейсовых куполов и их пространственно-временных соотношениях с палеопротерозойскими (карельскими) вулканогенно-осадочными комплексами. На природу купольных структур и их взаимоотношения с породами сортавальской серии существует несколько принципиально различных представлений:

- купола являются “палингенно-анатектическими выступами гранитоидного батолита”, тектоническими “бескорневыми” линзами, пластинами, блоками, выступами архейской коры Карельского кратона [Кратц, 1963; Лобач-Жученко и др., 1974 и др.];

- породы сортавальской серии являются энсиматическими образованиями (метаофиолиты и островодужные комплексы) и их соотношения с куполами являются результатом позднесвекофеннской коллизии [Иваников и др., 1997; Иваников и др., 1999; Peltonen et al., 1996; Богачев и др., 1999] и дивергентных тектонических процессов в режиме транспрессии, в результате чего породы архейского фундамента оказались совмещенными на одном структурном уровне с раннепротерозойскими супракрустальными образованиями [Морозов, 1999: Ладожская ...., 2020].

- гранито-гнейсы являются "окаймленными гранито-гнейсовыми куполами" [Eskola 1949], диапирами или неоднократно реоморфизованными гранитоидами архейского фундамента супракрустальных пород раннего протерозоя, выведенными на современную эрозионную поверхность в результате Свекофеннского тектогенеза [Судовиков, 1954; Григорьева, Шинкарев, 1981; Светов, Свириденко, Иващенко,1990].

Столь разнообразные представления о характере соотношений гранитоидов куполов с вулканогенно-осадочными образованиями сортавальской серии определили появление принципиально различных моделей геодинамического развития области сочленения континентальной коры эпиархейского Фенно-Карельского кратона и протерозойской ювенильной коры Свекофеннской провинции.

Ряд исследователей [Lahtinen et al., 2015; Геология и петрология ...., 2000; Kohonen, 1995], предполагая синхронность и формационно-геохимическое подобие пород сортаваальской серии со свекокарельскими комплексами зоны Тампере и офиолитами Оутокумпу и Йормуа юго-восточной Финляндии, рассматривают Раахе- 
Ладожскую зону в геодинамическом плане как результат свекофеннской коллизии энсиматической островной дуги, задугового бассейна и края континента.

В то же время, существуют представления, основанные на литологоформационном анализе, о протоплатформенной природе супракрустальных образований сортавальской серии, состоящей из продуктов эпиконтинентального мелководного осадконакопления и платобазальтового траппового вулканизма, и их стратиграфической корреляции с протоплатформенными людиковийскими образованиями заонежской свиты Онежской структуры южной Карелии [Светов, Свириденко, 1992].

В этой связи при расчленении и корреляции нижнекарельских вулканогенноосадочных комплексов северного Приладожья и идентификации их геодинамической природы особое значение приобретают методы изотопной геохронологии, позволяющие проводить сопоставление латерально разобщенных геологических комплексов, часто связанных с различными эндогенными процессами и источниками в коре и мантии, и устанавливать объективные критерии их соотношений во времени. По сравнению с палеопротерозойскими образованиями Раахе-Ладожской зоны на территории южной Финляндии для вулканогенно-осадочных толщь сортавальской серии и гранитоидов купольных структур в северном Приладожье существует явный дефицит изотопногеохронологических данных. Есть только одно определение U-Pb возраста гранитоидов

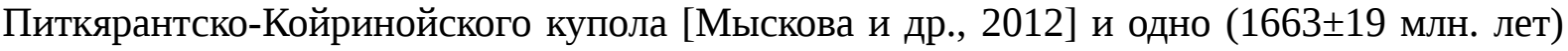
для вулканитов сортавальской серии [Геология и петрология..., 2000; Балтыбаев, Левченков, Левский, 2009]. На территории Финляндии в пределах Раахе-Ладожской зоны U-Pb изотопный анализ обломочных цирконов из осадков калевия (аналогов ладожской серии Приладожья) с использованием масс-спектрометра вторичных ионов свидетельствуют об архейском и протерозойском источниках вещества осадконакопления. Нижняя возрастная граница калевийских осадков определена по минимальному значению кластогенного циркона $(1907 \pm 15$ млн. лет) и составляет в пределах ошибки 1.9 млрд. лет [Huhma et al., 1991; Claesson et al., 1993], что несколько моложе принятому в нашей стране возрасту калевийского надгоризонта (1950 - 1920 млн. лет) [Семихатов, 1993; Общая стратиграфическая ...., 2002; Общая......., 2013] и минимального значение возраста детритового циркона $1918 \pm 14$ млн. лет из метапесчаников ладожской серии [Мыскова и др., 2012]. ]). Завершение осадконакопления ладожской серии фиксируется становлением группы малых интрузий

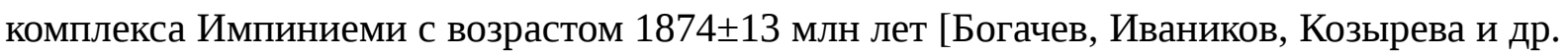
1999].

Результаты исследований, приведенные в настоящей статье, восполняют дефицит изотопных данных для Северного Приладожья и позволяют уточнить представления о возрасте, изотопном составе и источниках вулканогенно-осадочного комплекса сортавальской серии и гранитоидов Кирьявалахтинского выступа и на этой основе дать оценку геодинамической природе этих образований.

\section{АНАЛИТИЧЕСКИЕ МЕТОДЫ}

Содержания породообразующих оксидов в породах определены методом РФА по стандартной методике, концентрации редких (Li, Be, Sc, Cu, Zn, Ga, Y, Nb, Cs, Hf, Ta, 
Th, U) и редкоземельных элементов (Р3Э) - методом ICP-MS в Центральной аналитической лаборатории ВСЕГЕИ (Санкт-Петербург). Масс-спектроскопические измерения проводились трижды с использованием Rb, Re и In в качестве внутренних стандартов. Ошибка определения элементов Th, U, Lu, Yb, Er и Dy методом ICP-MS оценивается в 10-15\%, для остальных редких земель, Ti, Zr, Sr, Y не более 5\%.

Sm-Nd изотопно-геохимические исследования выполнены в Институте геологии и геохронологии докембрия РАН (г. Санкт-Петербург). Навески около 100 мг растертых в пудру образцов, к которым был добавлен смешанный изотопный индикатор ${ }^{149} \mathrm{Sm}-$ ${ }^{150} \mathrm{Nd}$, разлагались в тефлоновых бюксах в смеси $\mathrm{HCl}+\mathrm{HF}+\mathrm{HNO}_{3}$ при температуре $110^{\circ} \mathrm{C}$. $\mathrm{Sm}$ и Nd были выделены с помощью экстракционной хроматографии на колонках LNSpec (100-150 меш) фирмы Eichrom. Изотопные составы Sm и Nd измерялись на многоколлекторном масс-спектрометре TRITON TI в статическом режиме. Измеренные отношения ${ }^{143} \mathrm{Nd} /{ }^{144} \mathrm{Nd}$ нормализованы к отношению ${ }^{146} \mathrm{Nd} /{ }^{144} \mathrm{Nd}=0.7219$ и приведены к ${ }^{143} \mathrm{Nd} /{ }^{144} \mathrm{Nd}=0.511860$ в $\mathrm{Nd}$ стандарте La Jolla. Уровень холостого опыта за время исследований составил 0.03-0.2 нг для Sm, 0.1-0.5 нг для $\mathrm{Nd}$. Точность определения концентраций $\mathrm{Sm}$ и $\mathrm{Nd}$ составила $\pm 0.5 \%$, изотопных отношений ${ }^{147} \mathrm{Sm} /{ }^{144} \mathrm{Nd}= \pm 0.5 \%$, ${ }^{143} \mathrm{Nd} /{ }^{144} \mathrm{Nd}= \pm 0.005 \%(2 \sigma)$.

При расчете величин $\varepsilon \mathrm{Nd}(\mathrm{T})$ и модельных возрастов $\mathrm{TNd}(\mathrm{DM})$ использованы современные значения однородного хондритового резервуара (CHUR) по [Jacobsen, Wasserburg, 1984] $\left({ }^{143} \mathrm{Nd} /{ }^{144} \mathrm{Nd}=0.512638,{ }^{147} \mathrm{Sm} /{ }^{144} \mathrm{Nd}=0.1967\right)$ и $\mathrm{DM}$ по [Goldstein, Jacobsen, 1988] $\left({ }^{143} \mathrm{Nd} /{ }^{144} \mathrm{Nd}=0.513151,{ }^{147} \mathrm{Sm} /{ }^{144} \mathrm{Nd}=0.2137\right)$. Для учета возможного фракционирования $\mathrm{Sm}$ и $\mathrm{Nd}$ во внутрикоровых процессах для кислых и средних вулканитов рассчитаны двустадийные Nd-модельные возрасты TNd(DM-2st) [Keto, Jacobsen, 1987] с использованием среднекорового отношения ${ }^{147} \mathrm{Sm} /{ }^{144} \mathrm{Nd}=0.12$ [Taylor, McLennan, 2009].

Акцессорные цирконы выделены в минералогической лаборатории Института геологии и геохронологии докембрия РАН (Санкт-Петербург) по стандартной методике с использованием тяжелых жидкостей. U-Th-Pb датирование цирконов осуществлялось на ионном микрозонде SHRIMP-II в Центре изотопных исследований ВСЕГЕИ им. А.П. Карпинского (Санкт-Петербург). Измерения U-Pb отношений на SHRIMP-II проводились по методике, описанной в [Williams, 1998]. Интенсивность первичного пучка ионов кислорода составляла 4 нА, а диаметр пятна (кратера) - 18 мкм. Обработка полученных данных осуществлялась с использованием программы SQUID (Ludwig, 2000). U-Pb отношения нормализовались на значение 0.0668, приписанное стандартному циркону TEMORA [Black et al., 2003]. Погрешности единичных анализов приведены на уровне $1 \sigma$, а погрешности возрастов на уровне $2 \sigma$.

Так как исследование изотопного состава детритового циркона с использованием дорогостоящей (более 2.5 тыс. руб. за аналитическую точку) технологии ионного микрозонда SHRIMP-II не позволило выполнить минимальные статистические требования по количеству аналитических точек в детритовом цирконе ( $\geq 50$ конкордантных точек) для количественного определения времени осадконакопления, то при качественной оценки возраста и состава протолита в источнике сноса терригенного материала использовались аналитические данные с минимальным процентом дискордантности (<10\%). В работе из рассмотрения так же не исключались 
дискордантные значения (D>10\%) ${ }^{207} \mathrm{~Pb} /{ }^{206} \mathrm{~Pb}$ возраста циркона из магматических комплексов, так как они были использованы в сочетании с характером нормированного распределения РЗЭ для генетической интерпретации происхождения и эволюции расплавов (тип протолита, процессы контаминации и метаморфизма).

Содержания Р3Э в цирконе определялись на микрозонде Cameca IMS-4f в Институте микроэлектроники и информатики РАН (Ярославль) по методике [Федотова и др., 2008] в тех же точках, в которых была изучена U-Pb изотопная система на ионном микрозонде SHRIMP-II. Диаметр анализируемого участка не превышал более 15-20 мкм, относительная ошибка определения концентраций для большинства элементов не превышала 10-15\%, порог обнаружения в среднем составлял 10 мг/т. Содержание РЗЭ нормировалось на состав примитивной мантии [McDonough, Sun, 1995]. Символы названий минералов приведены по [Whitney, Evans, 2010].

В вулканогенно-осадочных образованиях сортавальской серии Северного Приладожья, несмотря на метаморфические преобразования высокотемпературной амфиболитовой фации, достаточно хорошо сохранились различные структурнотекстурные коматиитовых и толеитовых вулканитов и туфов, кислых и средних вулканитов, а также терригенных пород, что позволяет использовать при таксономической идентификации пород кайнотипную терминологию.

\section{ОСНОВНЫЕ ЧЕРТЫ ГЕОЛОГИЧЕСКОГО СТРОЕНИЯ}

В Сортавальской зоне развития гранитоидных куполов наиболее полные и представительные разрезы вулканогенно-осадочного комплекса сортавальской серии расположены в северо-восточном обрамлении Кирьявалахтинского выступа в районе пос. Харлу - оз. Тенъярви (рис. 1).

В современном эрозионном срезе Кирьявалахтинский выступ представлен биотитовыми плагио-гнейсами и гранито-гнейсами, как правило, в различной степени мигматизированными. Породы имеют грубо полосчатую текстуру, обусловленную чередованием более меланократовых полос по составу варьирующих от кварцевых диоритов до плагиогранитов и лейкократового материала плагио- и плагиомикроклинового состава, причем микроклин является наложенным и более поздним по отношению к общей гнейсовидности пород.

Вулканогенно-осадочные образования сортавальской серии развиты в обрамлении купольных структур в виде толщ мощностью от нескольких сот метров до первых километров моноклинального строения в разной степени смятых в изоклинальные складки субмеридионального простирания. Породы сортавальской серии имеют крутые (70-90²) и иногда опрокинутые пространственные соотношения с гранито-гнейсами куполов.

Несмотря на высокую степень регионального метаморфизма, отвечающего амфиболитовой фации, вулканогенно-осадочные породы, как правило, сохраняют первичные литологические признаки. В излившихся вулканитах хорошо различимы реликты подушечной, кластолавовой, миндалекаменной и порфировой текстур лавовых потоков, в вулканогенно-осадочных образованиях - бомбовые текстуры туфов, слоистые текстуры туффитов и терригенных пород. Эти особенности строения супракрустальных пород позволили провести детальную палеовулканологическую реконструкцию динамики и типов вулканических пароксизмов людиковийского вулканизма этой части 
северного Приладожья, связанного со «щитовым Кирьявалахтинским платобазальтовым стратовулканом» [Светов и др., 1990; Светов, Свириденко, 1992].

Более поздние исследования существенно уточнили представления о составе и происхождении вулканогенно-осадочных комплексов сортавальской серии, которые были разделены на четыре свиты принципиально отличающихся формационным и изотопно-геохимическим составом и отвечающих последовательным эпизодам вулканической активности [Вревский, Матреничев, 2007; Матреничев, Матреничев, 2010].

Нижняя вулканогенно-осадочная питкярантская свита представлена терригенными слоистыми кремнисто-карбонатными породами, перекрытыми тонкозернистыми углеродистыми алевролитами и вулканомиктовыми граувакками, которые находятся в тектонических соотношениях с гранитоидами Кирьявалахтинского купола. Общая мощность терригенных пород составляет не менее 250 м. Выше располагается горизонт граувакк и ааркозовых песчаников, мощностью 4-6 м, преобразованных в биотитовые микрогнейсы с большим количеством линзовидных прослоев кварцито-песчаников и кварц-полевошпатовых гравеллитов. Осадочные породы нижней толщи прорваны маломощными (2-10 м) субвулканическими дайками и интрузиями плагиогранит-порфиров, фельзит-порфиров и диоритов-порфиров (рис. 2). Литологическую последовательность питкярантской свиты завершает вулканогенная пачка мощностью до 150 м метаморфизованных толеитовых базальтов с прослоями лапиллевых и кристаллокластических туфов. Содержание и соотношения редких элементов в толеитовых базальтах характеризуются плоским спектром распределения редкоземельных элементов с небольшим обогащением ЛР3Э $\left([\mathrm{Ce} / \mathrm{Yb}]_{\mathrm{N}}=1.2-3.5\right)$ при содержании тяжелых редкоземельных элементов на уровне $10-14$ нормированных единиц (рис. 3 а)

Вышезалегающая петсеваарская свита в основании разреза представлена толщей переслаивания аркозовых кварцито-песчаников с магнетитом, углеродсодержащих алевролитов и аграувакк мощностью около 40 м. Терригенная толща перекрыта несколькими лавовыми потоками подушечных толеитовых базальтов общей мощностью 200-220 м. По сравнению с основными вулканитами питкярантской свиты для базальтов петсеваарской свиты характерна обогащенность $\mathrm{MgO}=7.5-11 \%$ и обедненность $\mathrm{TiO}_{2}=0.9-1.2 \%$ (табл. 1). Они характеризуются спектром распределения Р3Э, с небольшим обеднением ЛРЗЭ $\left([\mathrm{Ce} / \mathrm{Yb}]_{\mathrm{N}}=0.5-0.8\right)$, при содержании тяжелых на уровне 8 - 8.5 нормированных единиц (рис. За).

На породах петсеваарской свиты с признаками размыва и угловым несогласием залегают породы свиты харлу, разрез которой начинается с пачки мощностью до 30 м аркозовых песчаников с линзами гравеллитов и туфоконгломератов с гальками базальтов. Терригенные породы перекрыты толщей вулканитов, варьирующих по составу от трахибазальтов до трахиандезитов и трахитов лавовой и пирокластической (бомбовые туфы) (табл. 1, рис. 4) фаций общей мощностью 250 - 500 м. Вулканиты свиты харлу обогащены ЛРЗЭ $\left([\mathrm{Ce} / \mathrm{Yb}]_{\mathrm{N}}=4-5\right)$ при содержании тяжелых лантаноидов на уровне $\mathrm{Yb}=9-14$ нормированных единиц (рис. 3б, 5).

Завершает разрез сортавальской серии в изученном районе вулканогенноосадочная толща (ㅎиa тенъярви) метаморфизованных лав и туфов коматиитов, 
коматиитовых базальтов и базальтов (табл. 1). Отдельные потоки коматиитовых лав имеют мощности от 0.6 до 1.2 м и часто разделяются между собой прослоями кровельных лавобрекчий или кластолав и горизонтами слоистых туфов. В кластолавах встречаются обломки миндалекаменных коматиитов. Латеральные текстурные различия коматиитов проявляются в замещении коматиитов лавовой фации на слоистые туфы с высоким содержанием карбонатов. Базальты свиты тенъярви отличаются от вулканитов питкярантской и петсеваарской свит повышенной щелочностью, высокими содержаниями ЛРЗЭ ([Ce/Yb $\left.]_{\mathrm{N}}=2-4\right)$ и ТРЗЭ ( $\mathrm{Yb}=10-14$ нормированных единиц). Содержание лантаноидов в коматиитах характеризуются обедненостью ЛР3Э ([Ce/Yb $]_{\mathrm{N}}$ $=0.7-1.1$ ) при концентрации ТРЗЭ на уровне $4-8$ нормированных единиц (рис. Зв). Коматиитовые базальты близки к базальтам по содержанию ЛРЗЭ $\left([\mathrm{Ce} / \mathrm{Yb}]_{\mathrm{N}}=2-4\right)$, но имеют более высокое содержание ТРЗЭ.

\section{РЕЗУЛЬТАТЫ U-ТН-РВ (SIMS) ДАТИРОВАНИЯ ЦИРКОНА, ЕГО ГЕОХИМИЧЕСКИЙ СОСТАВ И SМ-ND ХАРАКТЕРИСТИКА ПОРОД}

Для определения возраста пород сортавальской серии и характера ее соотношения с гранитоидами куполов, возраста источников области сноса и оценки времени проявления метаморфических процессов было проведено изучение изотопного состава $\mathrm{Nd}$, геохимическое и изотопно-геохронологическое исследования акцессорных цирконов из гранито-гнейсов Кирьявалахтинского выступа, базальных граувакк нижней толщи и трахитов средней толщи сортавальской серии, а также, секущих вулканогенноосадочные толщи сортавальской серии, даек плагио- и диорит-порфиров.

Гранитоиды Кирьявалахтинского купола. Из среднезернистых плагиомикроклиновых лейкократовых гранито-гнейсов (табл. 2) вблизи тектонического контакта с породами сортавальской серии в районе пос. Харлу была отобрана проба (обр. 8003 в) массой около 5 кг. Морфологические особенности выделенной популяции циркона позволили разделить кристаллы на несколько разновидностей, среди которых наиболее распространенными являются короткопризматические, бледно коричневые, хорошо ограненные кристаллы со следами растворения и темно коричневые, хорошо ограненные короткопризматические кристаллы, так же со следами растворения. Все цирконы в катодолюминесценции (КЛ) характеризуются сложным внутренним строением и содержат ядро, обрастающее одной или более наружными оболочками более темного циркона (рис. 6). На диаграмме с конкордией, для магматического циркона из ядерных частей кристаллов, положение 11 аналитических точек изотопного состава U-Th-Pb (SIMS SHRIMP II) (табл. 2) апрокрисимируется дискордией, верхнее пересечение которой с конкордией отвечает возрасту $2695 \pm 13$ млн. лет $(\mathrm{CKBO}=1.6)$ (рис. 7a). Полученное значений возраста более чем на 30 млн. лет древнее возраста $2659 \pm 15$ млн. лет циркона из гранито-гнейсов Питкярантско-Койринойского купола [Мыскова и др., 2012].

Время метаморфических изменений гранитов, выраженных в появлении темных кайм обрастания призматических ядерных частей циркона, было оценено по 5 аналитическим точкам изотопного состава, образующих дискордию с верхним пересечением 2479 \pm 27 млн. лет $(\mathrm{CKBO}=0.87)$ (рис. 7б, табл. 2). 
Содержание и нормированное распределение РЗЭ в цирконе из ядерных частей и кайм обрастания имеют принципиальные отличия. Для ядерных частей распределение в целом соответствует «магматическому» типу распределению Р3Э [Hoskin, Schaltegger, 2003; Belousova et al., 2006; Федотова и др., 2008], с характерными положительной Сеи отрицательной $\mathrm{Eu}-$ аномалиями $\left(\mathrm{Ce} / \mathrm{Ce}^{*}=2.85-5.52 ; \mathrm{Eu} / \mathrm{Eu}^{*}=0.46-0.56\right)$ и фракционированным трендом нормированного распределения средних и тяжелых РЗЭ с $(\mathrm{Sm} / \mathrm{Yb})_{\mathrm{N}}$ отношением 0.04-0.02 (рис. 8, табл. 3).

Широкие темные каймы призматических кристаллов в сравнении с магматическими ядрами отчетливо обогащены Ү и РЗЭ, характеризуются отсутствием Сe аномалии $\left(\mathrm{Ce} / \mathrm{Ce}^{*}=0.91--0.98\right)$ и слабо выраженной отрицательной $\mathrm{Eu}$ аномалией $\left(\mathrm{Eu} / \mathrm{Eu}^{*}=0.45-0.96\right)$. Для кайм характернл менее выраженное фракционированное распределение тяжелых лантаноидов $\left([\mathrm{La} / \mathrm{Gd}]_{\mathrm{N}}=0.11-0.41\right.$ (рис. 8, табл. 3), что свидетельствует об их метаморфической природе (Hoskin, Schaltegger, 2003; Belousova et al., 2002, 2006; Федотова и др., 2008).

Результаты Sm-Nd изотопных исследований гранито-гнейсов Кирьявалахтинского купола (табл. 4), также свидетельствуют об их ювенильной природе $(\varepsilon \mathrm{Nd}=+1.5)$ и позднеархейском времени отделения протолита от деплетированной мантии (DM) (TNdDM = 2.85 млрд. лет) (табл. 4).

Вулканокластические граувакки нижней толщи питкярантской свиты сортавальской серии. Для определения минимального возраста заложения бассейна осадконакопления сортавальской серии была опробована базальная терригенная пачка питкярантской свиты мощностью более 18 м тонкополосчатых сланцев полевошпатового и кварц полевошпатового состава с реликтами псаммитовой структуры. По химическому составу породы относятся к грауваккам (табл. 1).

Общее количество акцессорного детритового циркона, выделенного из пробы массой около 2 кг граувакк (обр. 40301в, 6703) значительно меньше, чем было выделено из гранитов. Детритовый циркон из граувакк различается по цвету и морфологии. Преобладают зерна в той или иной степени окатанные, а также обломочные кристаллы. Значительно меньше субидиоморфных и идиоморфных кристаллов с пирамидальными и дипирамидальными окончаниями. Внутреннее строение зерен циркона по данным катодолюминесцентного изучения довольно разнообразно, но в большинстве зерен в той или иной степени проявлена осцилляционная зональность (рис. 9).

Изучение изотопного состава детритового циркона их граувакк, проведенное в 20 аналитических точках, показало мультимодальное распределение возрастов, отраженное на диаграмме с конкордией и на графике относительной вероятности распределения ${ }^{207} \mathrm{~Pb} /{ }^{206} \mathrm{~Pb}$ возрастов (рис. 10, табл. 5). В целом анализ совокупной выборки из 17 конкордантных значений возраста с процентом дискордантности меньше $10 \%$ позволил достаточно аргументировано предположить их связь с определенными породными комплексами и эндогенными событиями. Так наиболее многочисленная (>75\%) группа циркона с возрастом по ${ }^{207} \mathrm{~Pb} /{ }^{206} \mathrm{~Pb}$ в интервале 26002800 млн. лет совпадает в пределах ошибок с U-Th-Pb возрастом 2695 \pm 13 млн. лет циркона из гранитов Кирьявалахтинского выступа. Детритовые цирконы с возрастом в интервале 3110-3160 млн. лет в граувакках питкярантской свиты указывают на присутствие в области размыва для терригенных толщ основания разреза сортавальской 
серии не только неоархейских гранитоидов, но и мезоархейских источников, аналогичных ТТГ комплексам Водлозерского блока Фенно-Карельской области Фенноскандинавского щита.

Обе группы архейского циркона характеризуются магматическим типом (Hoskin, Schaltegger, 2003; Belousova et al., 2002, 2006; Федотова и др., 2008) нормированного распределения РЗЭ с характерными положительной Се-ой $\left(\mathrm{Ce} / \mathrm{Ce}{ }^{*} \mathrm{cp} .=2.90\right)$ и отрицательной Eu-ой $\left(\mathrm{Eu} / \mathrm{Eu}^{*} \mathrm{cp} .=0.29\right)$ аномалиями и фракционированным трендом нормированного распределения средних и тяжелых РЗЭ со средним значением отношения $\mathrm{Sm} / \mathrm{Yb})_{\mathrm{N}}=0.05$ и $(\mathrm{La} / \mathrm{Gd})_{\mathrm{N}}=0.07$ (рис. 11, табл. 6).

Два детритовых циркона с минимальными конкордантными значениями возраста по ${ }^{207} \mathrm{~Pb} /{ }^{206} \mathrm{~Pb}-1958 \pm 17$ млн лет $(\mathrm{D}=-5 \%)$ и $1973 \pm 21$ ( $\left.\mathrm{D}=0 \%\right)$ (табл. 5) возможно отражают вклад наиболее молодых пород в источники сноса терригенных пород, что позволяет принять эти значения в качестве минимального возрастного ограничения терригенных осадков питкярантской свиты, что хорошо соотносится с оценкой верхней возрастной границы пород сортавальской серии в целом по U-Th-Pb (SIMS) возрасту 1922 \pm 11 млн. лет диоритов “Терваоя” [Матреничев, Вревский, Сергеев и др. 2006], которые прорывают контакт пород сортавальской и ладожской серий.

Свекофеннские тектоно-термальные события (1.92-1.85 млрд. лет) практически не отразились в U-Pb изотопной системе циркона из гранитоидов Кирьявалахтинского выступа и только в популяции детритовых цирконов из граувакк питкярантской свиты получены значения возраста по ${ }^{207} \mathrm{~Pb} /{ }^{206} \mathrm{~Pb}$ в пределах 1800-1875 млн. лет в двух зернах с метаморфическими характеристиками содержания и распределения Р3Э (Ce/Ce*=0.970.89; Eu/Eu*= 0.85-0.58; [Sm/Yb $\left.]_{\mathrm{N}}-0.56-1.00\right)$ (рис. 11, табл. 6).

Дайки плагио- и диорит-порфиров. Базальная терригенная пачка питкярантской свиты прорвана маломощными (2-10 м) субвулканическими дайками плагио-порфиров (обр. 40301-а) и диорит-порфира (обр.16399) (табл. 7). Из них была выделена небольшая популяция циркона (рис. 13,14 ), в которой пригодными для исследования UTh-Pb изотопной системы и геохимии РЗЭ оказалось только 6 зерен. Для ядерных частей кристаллов циркона, имеющих “магматический” характер нормированного распределения Р3Э (Ce/Ce*=0.51-2.12; $\mathrm{Eu} / \mathrm{Eu}^{*}=0.10-0.09 ;[\mathrm{Sm} / \mathrm{Yb}]_{\mathrm{N}}=0.04 ;[\mathrm{La} / \mathrm{Gd}]_{\mathrm{N}}=0.03$ - 0.66) (рис. 13а, табл. 8), получены неоархейские конкордантные ( $D=2 \%$ и -3\%) значения по ${ }^{207} \mathrm{~Pb} /{ }^{206} \mathrm{~Pb}$ возраста (2827 \pm 19 и $2767 \pm 7$ млн. лет) (рис. 12, точки 1.1 и 3.1), что, вероятно, свидетельствует о происхождении первичных расплавов плагио- и диорит-порфиров из протолита в архейской континентальной коре. Этот источник фиксируется так же начальным изотопным составом неодима ( $\mathrm{NdT}=-4.8$ и -2.6) и модельном возрасте (TNdDM) 2796 и 2612 млн. лет (табл. 4) плагио- и диорит порфиров.

Дискордантное ( $\mathrm{D}=11 \%)$ значение возраста по ${ }^{207} \mathrm{~Pb} /{ }^{206} \mathrm{~Pb}$ и конкордантное $(\mathrm{D}=5 \%)$ значение $2247 \pm 23$ млн. лет, полученное для краевой части циркона из диоритпорфира, по всей вероятности связано с изменениями в изотопной системе циркона при наложенном метаморфизме, о чем свидетельствуют особенности состава и нормированного распределение РЗЭ - Се/Ce*= 0.33, Eu/Eu*=0.1, $(\mathrm{Sm} / \mathrm{Yb})_{\mathrm{N}}=0.134$, $(\mathrm{La} / \mathrm{Gd})_{\mathrm{N}}=0.44$ (рис. 13 а, табл. 8). Вероятно, эти же наложенные тектоно-термальные процессы отразились в U-Th-Pb изотопной системы в краевых частях двух кристаллов 
циркона с дискордантными значениями возраста по ${ }^{207} \mathrm{~Pb} /{ }^{206} \mathrm{~Pb}$ в интервале1890-1910 млн. лет.

Трахиандезибазальты свиты харлу сортавальской серии. Из образца (обр. 14399) бомбовых туфов трахиандезибазальтов (рис. 4) была выделена популяция циркона из которой пригодными для изучения U-Th-Pb изотопной системы и состава РЗЭ оказалось 9 кристаллов различной морфологии и внутреннего строения (рис. 14). Полученные значения изотопного возраста циркона по ${ }^{207} \mathrm{~Pb} /{ }^{206} \mathrm{~Pb}$ имеют бимодальное распределение - 2700-2850 млн. лет и 1800 -2050 млрд. лет (табл. 7, рис. 15). Морфология и возраст (2718-2782 млн. лет) ядерных частей в короткопризматических цирконах указывает на их ксеногенную природу, связанную с плавлением корового протолита неоархейского возраста. Так как в популяции циркона присутствуют также и кристаллы с значениями дискордантными возраста в интервале 2000-2130 млн. лет, то, вероятно, первичные расплавы трахиандезибазальтов могли быть контаминированы нижележащими ятулийскими образованиями. Одно зерно циркона с конкордантным $(\mathrm{D}=-3 \%)$ значением возраста $1837 \pm 70$ млн. лет характеризуется метаморфическими характеристиками содержания и распределения Р3Э (Ce/Ce*=1.6; $\mathrm{Eu} / \mathrm{Eu}^{*}=0.69$; $[\mathrm{Sm} / \mathrm{Yb}]_{\mathrm{N}}=0.13,[\mathrm{La} / \mathrm{Gd}]_{\mathrm{N}}=0.49$ ) (рис. 13б, табл. 8), что вероятно можно связать со свекофеннскими тектоно-термальными событиями. Источником первичных расплавов субщелочных вулканитов свиты харлу вероятно являлась архейская континентальная литосфера, что запечатлено в их начальном изотопном составе ( $\varepsilon N d T c p=-4.36)$ и неоархейском модельном возрасте (TNdDM) 2606 млн. лет (табл. 4).

\section{ОБСУЖДЕНИЕ РЕЗУЛЬТАТОВ}

В докембрийской геологической эволюции Земли переход от архея к протерозою ознаменовался этапом (2.5-2.4 млрд. лет) заложения глобальной системы континентального рифтогенеза суперконтинента Кенорленд (Гуронская супергруппа Канадского щита, супергруппы Трансвааль и Грикваленд Капваальского кратона, Карельская эонотема Балтийского щита), тектоническая природа которого определялась плюмовой мантийной геодинамикой [Puchtel I. S. et al., 1999]. Для Карело-Кольского эпиархейского кратона палеопротерозойский рифтогенез проявился в нескольких типах интракратонных структур, отличающихся временем заложения, особенностями литолого-формационного состава и тектонического строения.

K таким структурам относятся в первую очередь две наиболее крупных и протяженных системы рифтогенных структур Фенно-Карельской (Киттиля - ПанаКуолоярви - Лехта - Ветреный пояс) и Кольско-Норвежской (Пасвик-Полмак - Печенга - Имандра-Варзуга) областей Фенноскандинавского щита с мощным и разнообразным мантийным и корово-мантийным магматизмом. Кроме того, палеопротерозойский тектогенез Карело-Кольского эпиархейского кратона проявился в формировании внутриконтинентальных бассейнов (Онежская мульда) с развитием платформенного осадконакопления и платобазальтового магматизма.

Своеобразие тектонического строения северного Приладожья позволяет выделить этот регион в качестве еще одного типа палеопротерозойского перикратонного рифтогенеза, общее геологическое и тектоническое строение которого во многом подобно архейским гранит-зеленокаменным областям древних кратонов. 
Примечательно, что дискуссии о характере взаимоотношений верхнекарельских (людиковийских) вулканогенно-осадочных структур с гранитоидами куполов аналогичны с противоречивыми представлениями о геодинамических взаимоотношениях супракрустальных комплексов зеленокаменных поясов с окружающими их тоналит-трондъемит-гранитными (ТТГ) комплексами [см. например Herzberg, Rudnick, 2012; Van Kranendonk M. et al., 2007; Taylor, McLennan. 2009 p].

Практически синхронно с поздними стадиями (2.0 - 1.92 млрд. лет) развития интракратонного рифтогенеза Карело-Кольского эпиархейского кратона происходили заложение и сложная тектоническая эволюция свекофеннид вдоль его юго-восточной окраины. Благодаря многолетним исследованиям финских геологов [Hietanen, 1975, Gaal, 1986; Lahtinen et al., 2015; Nironen, 1997, 1989, 2017; Kara et al., 2018 и др.] геодинамические модели области сочленения эпиархейского кратона со Свекофеннской областью наиболее аргументированно описываются в терминах аккреционноколлизионных геодинамических механизмов формирования ювенильной коры в цикле Уилсона. В основе этих представлений лежит геодинамическая интерпретация литолого-формационного и изотопно-геохимического состава свекофеннских вулканоплутонических комплексов южной Финляндии. Ключевыми объектами в таких моделях является офиолитовые комплексы Иормуа и Оутокумпу с возрастом $\leq 1.94$ млрд. лет [Peltonen et al., 1998], которые обычно интерпретируются как обдуцированные на кратон реликты океанической коры начальных стадий раскрытия т.н. «людиковийского океана» или окраинного рифта [Lahtinen et al., 2015]. Присутствие в клинопироксенитах Иормуа нескольких групп циркона как архейского возраста от $2747 \pm 8$ до $3206 \pm 3$ млн лет, так и палеопротерозойского (2030 - 1940 млн. лет) объясняется участием архейской субконтинентальной литосферной мантии на начальной стадии раскрытия океана [Peltonen, 2003; Lahtinen, 2012; Lahtinen et al., 2015]. В дальнейшем, вплоть до 1.83 млрд. лет, ювенильное корообразование свекофеннид и их тектоническая эволюция в рамках этим моделей определялась разнонаправленной субдукцией океанической коры, формированием юных и зрелых островных дуг, их аккрецией и коллизией. В итоге менее чем за 100 млн. лет был сформирован основной объем континентальной коры аккреционного орогена мощностью не менее 40 км и протяженностью в широтном (современном) направлении более чем на 400 км.

Исходя их общих теоретических и экспериментальных петрологических представлений о процессах генерации вулкано-плутонических известково-щелочных комплексов в надсубдукционнных геодинамических обстановках (10-40 \% частичное плавление океанического слэба в различных РТ $\mu$ условиях) [например Annen et al., 2006] можно констатировать, что амплитуда раскрытия людиковийского океана, при теоретической мощности океанической коры не менее современной (т.е. $\geq 5-7$ км), составляла более 2000 км. Таким образом, очевидно, что скорость, интенсивность и масштаб корово-мантийных процессов ювенильного корообразования свекофеннид имели принципиально иную геодинамическую природу по сравнению с интракратонными рифтогенным корообразованием на эпиархейском кратоне, в том числе в его перикратонной части северного Приладожья.

Полученные новые изотопно-геохимические данные свидетельствуют, что формирование вулканогенно-осадочного комплекса сортавальской серии ( $\geq 1920$ млн 
лет) происходило в условиях континентального рифтогенеза на краю эпиархейского кратона вслед за суйсарским платобазальтовым вулканизмом (1.95-1.99 млрд. лет) в Онежской структуре Фенно-Карельской области и ферро-пикритами свиты матерт

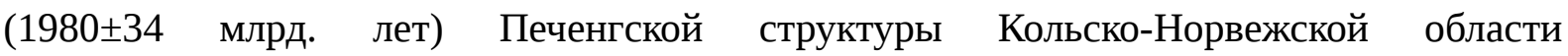
Фенноскандинавского щита. Палеопротерозойский интракратонный рифтогенез Фенноскандинавского щита был обусловлен, как полагают некоторые исследователи [Puchtel I. S. et al., 1999], эволюцией долгоживущего (2.45- 1.9 млрд. лет) обширного мантийного плюма.

Присутствие неоархейского протолитового циркона в трахиандезибазальтовых туфах и дайках плагио- и диорит порфиров нео- и мезоархейского ( 3.1, 2.6-2.8 млрд. лет) и палеопротерозойского (сумийского) (2.47 -2.52 млрд. дет) возраста и кластогенного циркона (2.6-2.8 млрд. лет) в вулканомиктовых граувакках питкярантской свиты сортавальской серии свидетельствует, что неоархейские гранитоиды являлись не только фундаментом супракрустальных толщ сортавальской серии, но и служили одним из источников терригенного материала в области размыва при накоплении базальных граувакк сортавальской серии. Кроме того, еще одним источником сноса вероятно служили мезоархейские ТТГ комплексы Водлозерского блока Фенно-Карельского эпиархейского кратона

Наиболее молодой источник терригенного материала для граувакк питкярантской свиты представлял собой результат переотложения незрелых продуктов размыва вулканитов раннелюдиковийского возраста (1958-1973 млрд. лет). Присутствие кластогенного циркона с U-Th-Pb возрастом 2460 -2500 млн. лет в осадках ладожской серии [Мыскова и др., 2012] свидетельствует, что гранитоиды куполов длительное время, вплоть до калевия, были одним из источников сноса терригенного материала в палеобассейн Северного Приладожья.

Исследование U-Th-Pb возраста детритовых цирконов из вулканомиктовых граувакк питкярантской свиты позволили принять с учетом ошибок определения возраста кластогенных цирконов минимальные конкордантные значения в интервале 1940- 1990 млн лет в качестве вероятного временного интервала окончания процессов накопления терригенных пород, что согласуется с оценкой максимального возраста пород сортавальской серии в целом по U-Th-Pb (SIMS) возрасту 1922 11 млн. лет диоритов “Терваоя” [Матреничев, Вревский, Сергеев и др. 2006], которые прорывают контакт пород сортавальской и ладожской серий.

Полученные данные позволяют считать, что ко времени начала свекофеннской субдукции и формирования бимодальных вулкано-плутонических комплексов юных островных дуг Пюхисалми и кислых вулканитов сланцевого пояса Саво (1920-1890 млн. лет) [Lahtinen, 2012; Kousa et al., 1994], в перикратонной части Фенно-Карельского эпиархейского кратона на коре континентального типа уже произошло накопление вулканогенно-осадочного комплекса сортавальской серии, его метаморфизм, эрозия и несогласное перекрытие турбидитами ладожской серии. Последние, по крайней мере, на 10 млн. лет древнее граувакковых турбидитов Сланцевых поясов Тампере и Хамеелинна, содержащих наиболее молодой кластогенный циркон с U-Pb возрастом $1907 \pm 15$ [Huhma et al., 1991]. 


\section{ВЫВОДЫ}

На основании полученных новых геологических и изотопно-геохимических данных для вулканогенно-осадочных пород сортавальской серии и гранитоидов Киръяволахтинского выступа можно сделать следующие выводы.

Гранитоиды Кирьявалахтинского выступа имеют неоархейский возраст $2695 \pm 13$ млн. лет, ювенильную природу $(\varepsilon \mathrm{NdT}=+1.5)$ и испытали тектоно-метаморфические преобразования (реоморфизм) раннепротерозойского (сумийского) времени (2.45-2.50 млрд. лет), запечатленные в U-Th-Pb изотопной системе оболочек древних ядер кристаллов циркона. В изученных гранитоидах воздействие свекофеннского тектонотермального события (1850-1890 млн. лет) практически не отразились в U-Th-Pb изотопной системе циркона и $\mathrm{Sm}-\mathrm{Nd}$ изотопной системе пород (TNdDM= 2.86 млрд. лет, $\varepsilon \mathrm{NdT}=+1.5)$. Вероятно, это было связано с закрытостью изотопной системы циркона и породы в целом при сфекофеннском орогенезе и реализации этих структурно-метаморфических процессов главным образом в некомпетентных слоистых вулканогенно-осадочных породах сортавальской серии, о чем свидетельствует присутствие в граувакках питкяранской свиты единичных зерен циркона с возрастом 1800-1875 млн. лет и геохимическими характеристиками распределения РЗЭ метаморфического типа. Вероятно, существенное влияние на реологическое состояние и реоморфизм гранитоидов выступов фундамента при свекофеннских структурнометаморфических процессах имел размер этих блоков. Так, в наиболее крупном Кирьявалахтинском выступе, имеющим “трапецивидную” форму, не зафиксированы цирконы свекофеннского возраста, тогда как плагио-микроклиновые граниты самого небольшого “грибовидного” выступа Хавус имеют конкордантный возраст $1970 \pm 6$ млн. лет, а архейские цирконы в них не установлены [Морозов и др., 2020].

Плагио-микроклиновые гранитоиды Кирьявалахтинского выступа не только более чем на 30 млн. лет древнее плагиомикроклиновых гранито-гнейсов Питкярантско-Койринойского выступа (2659 \pm 15 млн. лет) [Мыскова и др., 2012], но и имеют ювенильную природу протолита $(\varepsilon \mathrm{NdT}=+1.5)$ (табл. 3) в отличие от коровой природы $(\varepsilon \mathrm{NdT}=-6.2)$ протолита гранитов Питкеранского выступа. Эти данные являются еще одним аргументом, подтверждающим правомерность подразделение гранитоидных куполов Северного Приладожья на две структурно-морфологические группы - Сортавальскую и Питкярантскую [Ладожская ....., 2020].

Полученные изотопные данные позволяют считать, что заложение и развитие вулканогенно-осадочного комплекса сортавальской серии происходило на гетерогенной и полихронной (3.1 -2.46 млрд. лет) континентальной коре Фенно-Карельского эпиархейского кратона. U-Th-Pb возраст кластогенных цирконов в граувакках и вариации начальных изотопных отношений ${ }^{143} \mathrm{Nd} /{ }^{144} \mathrm{Nd}$ в основных $(\varepsilon \mathrm{NdT}=-1.4-+1.8)$ и субщелочных ( $\varepsilon \mathrm{NdT}=0$ т -5.4 до -4.0) метавулканитах сортавальской серии также свидетельствуют, что континентальная литосфера Фенно-Карельского этиархеского кратона была не только областью сноса терригенного материала сортавальской серии, но и служила источником и контаминантом для первичных расплавов вулканических серий.

Завершающие стадии эндогенной активности при эволюции вулканогенноосадочного комплекса сортавальской серии фиксируются временем кристаллизации 
гипабиссальных даек гранит- и диорит-порфиров, секущих вулканогенно-осадочные толщи, и определяется временным интервалом в пределах 1890-1910 млрд. лет. Источником и контаминантом первичных расплавов этих гипабиссальных интрузивных тел являлись коровые породы фундамента с $\varepsilon N d T$ от -4.8 до -2.6 неоархейского и раннепротерозойского возраста (от 2.8 до 2.2 млрд. лет).

Работа выполнена в рамках НИР 0153-2019-0001 Госзадания ИГГД РАН.

\section{СПИСОК ЛИТЕРАТУРЫ}

Балтыбаев Ш. К., Левченков О.А., Левский Л.К. Свекофеннский пояс Фенноскандии: пространственно-временная корреляция раннепротерозойских эндогенных процессов. СПб.: Наука, 2009, 328 с.

Богачев В.А., Иваников В.В., Козырева И.В. и др. U-Pb цирконовое датирование синорогенных габбро-диоритовых и гранитоидных интрузий Северного Приладожья // Вест. СПбГУ, 1999, сер. 7, вып. 3 (№21), с. 23-33.

Вревский А..Б., Матреничев В.А. Геохронологическое и изотопногеохимическое обоснование энсиалической природы сортавальской серии, Фенноскандинавский щит. «Геодинамика, магматизм, седиментогенез и минерагения Северо-запада России», Петрозаводск, ИГ КарНЦ РАН, 2007, с.79-82.

Геология и петрология свекофеннид Приладожья. СПб ун-т, 2000, 200 с.,

Григорьева Л.В., Шинкарев Н.Ф. Условия образования купольных структур в Приладожье // Изв. АН СССР, сер. геол., 1981, № 3, с. 41-45.

Иваников В.В., Филиппов Н.Б., Богачев В.А., Кольцов А.А. Метавулканиты окаймленных куполов Северного Приладожья - покровы платобазальтов или офиолитовые надвиги? // Докембрий Северной Евразии. СПб: ИГГД РАН, 1997, с.36-37.

Иваников В.В., Филиппов Н.Б., Богачев В.А., Мурадымов Г.Ш. Минералогогеохимические признаки офиолитовой ассоциации в Приладожье. Рифтогенез, магматизм, металлогения докембрия. Корреляция геологических комплексов Фенноскандии. //Материалы междунар. конф. Петрозаводск, 1999, с. 53-55.

Крати К.О. К расчленению и терминологии протерозоя Карелии //Изв. Карельского и Кольского фил. АН ССР, 1963, №2, с.3-15.

Ладожская протерозойская структура (геология, глубинное строение, и минерагения). Петрозаводск, КНЦ РАН, 2020, 436 с.

Лобач-Жученко С.Б., Чекулаев В.П., Байкова В.С. Эпохи и типы гранитообразования в докембрии Балтийского щита. // Л. Наука, 1973, 208 с.

Матреничев А.В., Матреничев В.А. Петрология людиковийского вулканизма Онежской структуры и Раахе-Ладожской зоны. Балтийский щит // Сборник трудов молодых ученых ИГГД РАН. Изд-во Политехн. ун-та, СПб. 2010. с. 223-255

Матреничев В.А., Вревский А.Б., Сергеев С.А., Матуков Д.А. Граница между людиковием и калевием в северном Приладожье: геологические взаимоотношения и изотопный возраст. // ДАН, 2006, т.407, №5, с.654-649.

Матреничев В.А., Степанов К.И., Пупков О.М. и др. Стратиграфия и особенности вещественного состава раннепротерозойских вулканитов Сортавальского поднятия (Северное Приладожье) // Вест. СПбГУ, 2004, вып. 2, с.31-44.

Морозов Ю.А. О роли транспрессии в формировании структуры Свекокарелид Балтийского щита// Геотектоника, 1999, № 4, с. 37-50

Морозов Ю.А., Кулаковский А.Л., Смульская А.И. Структуры Северного Приладожья и модели эволюции. // В кн.: Ладожская протерозойская структура (геология, глубинное строение, и минерагения). Петрозаводск, КНЦ РАН, 2020, с. 162185. 
Мыскова Т.А., Милькевич Р.И., Львов П.А. U-Pb геохронология (SHRIMP-II) цирконов из метаосадков ладожской серии (Северное Приладожье, Балтийский щит) // Стратиграфия. Геологическая корреляция, 2012, т. 20, № 2, с. 55-67.

Общая стратиграфическая шкала нижнего докембрия России. Апатиты: Изд-во КНЦ РАН, 2002, 13 с.

Общая стратиграфическая шкала России. М. 2013.

Ранний докембрий Балтийского щита. СПб: Наука, 2005, 711 с.

Светов А.П., Свириденко Л.П. Стратиграфия докембрия Карелии. Сортаваальская серия свекокарелид Приладожья. Петрозаводск. КарНЦ РАН, 1992, 152 c.

Светов А.П., Свириденко Л.П., Иващенко В.И. Вулкано-плутонизм свекокарелид Балтийского щита. Петрозаводск. КарНЦ РАН, 1990, 321 с.

Семихатов М.А. Новейшие шкалы общего расчленения докембрия: сравнение // Стратиграфия и геологическая корреляция, 1993, т.1б, №.1, с. 6-20.

Судовиков Н.Г. Тектоника, метаморфизм, мигматизация и гранитизация пород ладожской формации // Тр. ЛАГЕД АН СССР, 1954, вып. 4, 190 с.

Федотова А.А., Бибикова Е.В., Симакин С.Г. Геохимия циркона (данные ионного микрозонда) как индикатор генезиса минералов при геохронологических исследованиях // Геохимия, 2008, № 9, с.980-997.

Annen C., Blundy J. D., Spark R. S. J. The Genesis of Intermediate and Silicic Magmas in Deep Crustal Hot Zones // J. Petrol, 2006, v. 47, № 3, p. 505-539

Belousova E.A., Griffin W.L., O’Reilly S.Y. Zircon crystal morphology, trace element signatures and $\mathrm{Hf}$ isotope composition as a tool for petrogenetic modelling: examples from Eastern Australian Granitoids //J. Petrol, 2006, v. 47, N 2, p. 329-353.

Black, L.P., Kamo, S.L. et al. TEMORA 1: a new zircon standard for U-Pb geochronology //Chemical Geology, 2003, v. 200, p. 155-170.

Claesson S., Huhma H., Kinny P.D., Williams, I.A. Svecofennian detrital zircon ages - implications for the Precambrian evolution of the Baltic Shield // Precambrian Res., 1993, v.64, p. 109-130.

Escola P. The problem of mantled gneiss domes // Quart. Journal Geol. Soc. London. 1949, v. 104, p.461-476.

Gaál G. 2200 million years of crustal evolution: the Baltic Shield // Geol. Surv. of Finland, 1986, bull. 58, p. 149-168.

Herzberg C., Rudnick R. Formation of cratonic lithosphere: an integrated thermal and petrological model. //Lithos. 2012. V.149. P. 4-15.

Hietanen A. Generation of potassium poor magmas in the northern Sierra Nevada and the Svecofennian in Finland// J. Res. U.S. Geol. Surv., 1975, v. 3, p. 631-645.

Hoskin P.W.O., Schaltegger U. Zircon // Rev. Mineral. Geochem., 2003, v. 53, p. 2762.

Huhma H., Claesson S., Kinny P.D., Williams I.S. The growth of the Early Proterozoic crust: new evidence from Svecofennian detrital zircons // Terra Nova, 1991, v. 3, № 2, p. 175-179.

Jacobsen S.B., Wasserburg G.J. Sm-Nd Evolution of Chondrites and Achondrites // Earth Planet. Sci. Lett., 1984, v. 67, p. 137-150.

Kara J., Väisänen M., Johansson A., Lahaye Y., O’Brien H., Eklund O. 1.90-1.88Ga arc magmatism of central Fennoscandia: geochemistry, U-Pb geochronology, Sm-Nd and LuHf isotope systematics of plutonic-volcanic rocks from southern Finland // Geologica Acta, 2018, v.16, N 1, p. 1-23.

Kohonen $J$. From continental rifting to collisional crustal shortening Paleoproterozoic Kaleva metasediments of the Haytianen area in North Karelia, Finland // 
Geol. Surv. Finland Bul., 1995, v. 380, 82 p.

Kousa J., Marttila E., Vaasjoki M. Petrology, geochemistry and dating of Paleoproterozoic metavolcanic rocks in the Pyhäjärvi area, central Finland. In: Nironen, M. \& Kähkönen, Y. (eds) Geochemistry of Proterozoic supracrustal rocks in Finland. //Geological Survey of Finland, 1994, Special Paper 19, p. 7- 27.

Lahtinen $R$. Main geological features of Fennoscandia.//Geological Survey of Finland. Special Paper, 2012, v. 53, p. 13-18

Lahtinen R., Huhma H., Lahaye Y., Kousa J., Luukas J. Archean-Proterozoic collision boundary in central Fennoscandia: Revisited // Precambrian Research, 2015, v. 261, p. $127-165$.

Ludwig, K.R, SQUID 1.00, a User's Manual; Berkeley Geochronology Center Special Publication, 2000, N 2, 2455 Ridge Road, Berkeley, CA 94709, USA.

McDonough W.F., Sun S.-S. The composition of the Earth // Chemical Geology, 1995, v. 120, p. 223-253.

Nironen M. Emplacement and structural setting of granitoids in the early Proterozoic Tampere and Savo Schist Belts, Finland-implications for contrasting crustal evolution //Geol. Surv. Finland Bull., 1989, v. 346, 83p.

Nironen M. The Salittu Formation in southwestern Finland, part II: Picritic-basaltic volcanism in mature arc environment // Bulletin of the Geological Society of Finland, 2017, v. 89, p. 5-19.

Nironen M. The Svecofennian Orogen: a tectonic model // Precambrian Res., 1997, v.86, p. 21-44.

Peltonen P., Kontinen A., Huhma H. Petrogenesis of the mantle sequence of the Jormua ophiolite (Finland): melt migration in the upper mantle during Palaeoproterozoic continental break-up // J. Petrol., 1998, v. 39, p. 297-329.

Peltonen P., Kontinen A., Huhma H. Petrology and geochemistry of metabasalts from the 1.95 Ga Jormua Ophiolite, northeastern Finland // J. Petrol., 1996, v.37, p.1359-1383.

Peltonen P., Manttari I., Huhma H., Kontinen A. Archean zircons from the mantle: the Jormua ophiolite revisited // Geology, 2003, v.7, p.645-648.

Ploegsma M., Westra L. The early Proterozoic Orija"rvi triangle (southwest Finland): a key area on the tectonic evolution of the Svecofennides // Precambrian Res., 1990, v.47, p.51- 69.

Puchtel I. S., Brugmann G. E., Hofmann A. W. Precise Re-Os mineral isochron and $\mathrm{Pb}-\mathrm{Nd}-\mathrm{Os}$ isotope systematics of a mafic-ultramafic sill in the $2.0 \mathrm{Ga}$ Onega plateau (Baltic Shield) // Earth Planet. Sc. Lett., 1999, v. 170, p. 447-461.

Sederholm J. J. On migmatites and associated Pre-Cambrian rocks of southwestern Finland, Part III. The Åland Islands. Bulletin de la Commission Géologique de Finlande, 1934, v.107, 68p.

Taylor S.R., McLennan S.M. Planetary crusts: Their composition, origin and evolution. Cambridge: Cambridge University Press, 2009, 400 p.

Van Kranendonk M. et al. Paleoarchean development of a continental nucleus: the East Pilbara terrane of the Pilbara craton, Western Australia // Earth's Oldest Rocks. 2007. P.307-337.

Wetherill G.W. Discordant uranium-lead ages. // Trans. Amer. Geophys. Union, 1956, v. 37, p. 320-326.

Whitney D.L., Evans B.W. Abbreviations for names of rock-forming minerals // Amer. Mineral., 2010, v. 95, p. 185-187.

William I.S. U-Th-Pb Geochronology by Ion Microprobe. In: McKibben, M.A., Shanks III, W.C. and Ridley, W.I. (eds.), Applications of microanalytical techniques to 
understanding mineralizing processes // Reviews in Economic Geology, 1998, v.7, p. 1-35. 
Рис. 1. а) Схема тектонического строения Фенноскандинавского щита. (1 архейская кора; 2 - палеопротерозойские (2.45 -1.90 мдрд лет) вулканогенно-осадочные комплексы; 3 - кора архей-протерозойского возраста: а - Фенно-Карельская и б - КольскоНорвежская области; 4 -Лапландско-Кольский ороген; 5 - граница эпиархейского кратона; 6 - платформенный чехол.

б) Схема геологического строения Северного Приладожья. 1 - гранито-гнейсовые купола: Сортавальская зона (1 - Сортавальский, 2 - Кирьявалахтинский), Питкярантская зона (3Мурсульский, 4- Импилахтинский, 5 - Кокосельский, 6 - Койринойский-Питкяранский); 2 - людиковий (сортавальская и питкярантская серии); 3 - калевий (ладожская серия).

Рис. 2. Базальные граувакки сортавальской серии (40301в) и секущая дайка плагиопорфира (40301а).

Рис. 3. Нормированное к примитивной мантии (ПМ) распределение редкоземельных элементов в основных и высокомагнезиальных вулканитах сортавальской серии (а -базальты питкярантской 1-5 и петсеваарской свит 6-9; б - трахтандезибазальты свиты харлу; в -базальты 1, коматиитовые базальты 2 и коматииты 3 свиты тенъярви).

Рис. 4. Бомбовые туфы трахиандезибазальтов, свита харлу.

Рис. 5. Нормированное к примитивной мантии (ПМ) распределение редкоземельных элементов в трахибазальтах $(1,2,3)$ свиты харлу, дайках диоритпорфиров (4) и плагио-порфиров $(5,6)$, гранитоидах Кирьявалахтинского выступа (7).

Рис. 6. Микрофотографии кристаллов циркона из гранитоидов Кирьявалахтинского выступа в режиме катодолюминесценции. Цифры на фото соответствуют аналитическим точкам в табл., диаметр кратера 20 мкм.

Рис. 7. Диаграмма с конкордией для ядерных частей (а) и кайм (б) циркона из лейкогранитов Кирьявалахтинского выступа. Цифры на рис. соответствуют аналитическим точкам в табл. 1.

Рис. 8. Нормированное к примитивной мантии (ПМ) распределение редкоземельных элементов в цирконе из гранитоидов Кирьявалахтинского выступа.

Рис. 9. Микрофотографии кристаллов циркона из вулканокластических граувакк нижней части питкярантской свиты в режиме катодолюминесценции. Цифры на фото соответствуют аналитическим точкам в табл. 5, диаметр кратера 20 мкм.

Рис. 10. Диаграмма с конкордией (а) и график относительной вероятности распределения ${ }^{207} \mathrm{~Pb} /{ }^{206} \mathrm{~Pb}$ возрастов циркона (б) из вулканокластических граувакк нижней части питкярантской свиты.

Рис. 11. Нормированное к примитивной мантии (ПМ) распределение редкоземельных элементов в цирконе из вулканокластических граувакк нижней части питкярантской свиты. Цифры на рис. соответствуют аналитическим точкам в табл. 6.

Рис. 12. Диаграмма с конкордией (а) и график относительной вероятности распределения ${ }^{207} \mathrm{~Pb} /{ }^{206} \mathrm{~Pb}$ возрастов циркона (б) из даек плагио-порфира и диоритпорфиров. Цифры на рис. соответствуют аналитическим точкам в табл. 1.

Рис. 13. Нормированное к примитивной мантии (ПМ) распределение редкоземельных элементов в цирконе из дайки плагио-порфира (40301а) и диоритпорфира (16399) (А) и в цирконе из вулканокластических трахиандезибазальтов свиты харлу (Б).

Рис. 14. Микрофотографии кристаллов циркона из трахиандезибазальтов свиты харлу и из даек плагио-порфира и диорит-порфиров (1.2, 2.1, 3.1, 3.2) в режиме 
катодолюминесценции. Цифры на фото соответствуют аналитическим точкам в табл. 7, диаметр кратера 20 мкм.

Рис. 15. Диаграмма с конкордией (а) и график относительной вероятности распределения ${ }^{207} \mathrm{~Pb} /{ }^{206} \mathrm{~Pb}$ возрастов циркона (б) из трахиандезибазальтов свиты харлу. 
Таблица 1. Химический состав (вес.\%) пород сортавальской серии, гранитоидов Кирьявалахтинского выступа и поздних даек

\begin{tabular}{|c|c|c|c|c|c|c|c|c|c|c|c|c|}
\hline & $\mathrm{SiO}_{2}$ & $\mathrm{TiO}_{2}$ & $\mathrm{Al}_{2} \mathrm{O}_{3}$ & $\mathrm{FeO}^{*}$ & $\mathrm{MnO}$ & $\mathrm{MgO}$ & $\mathrm{CaO}$ & $\mathrm{Na}_{2} \mathrm{O}$ & $\mathrm{K}_{2} \mathrm{O}$ & $\mathrm{P}_{2} \mathrm{O}_{5}$ & ппп & Сумма \\
\hline 1 & 58.00 & 0.70 & 16.10 & 7.08 & 0.14 & 3.55 & 7.05 & 4.5 & 0.88 & 0.18 & 1.08 & 99.26 \\
\hline 2 & 68.90 & 0.18 & 17.20 & 1.88 & 0.02 & 1.06 & 2.52 & 6.15 & 0.83 & 0.07 & 1.05 & \begin{tabular}{|l|}
99.87 \\
\end{tabular} \\
\hline 3 & 69.97 & 0.18 & 15.78 & 2.12 & 0.05 & 1.00 & 3.36 & 5.36 & 0.93 & 0.07 & & \begin{tabular}{|l|}
98.82 \\
\end{tabular} \\
\hline 4 & 73.90 & 0.14 & 13.90 & 1.13 & 0.03 & 0.43 & 1.11 & 4.18 & 3.85 & 0.05 & 1.06 & \begin{tabular}{|l|}
99.78 \\
\end{tabular} \\
\hline 5 & 66.05 & 0.22 & 17.89 & 3.13 & 2.82 & 0.07 & 1.12 & 4.28 & 5.19 & 0.70 & 0.13 & 101.60 \\
\hline 6 & 60.12 & 0.81 & 18.64 & 5.08 & 0.05 & 4.15 & 1.95 & 5.31 & 2.25 & 0.06 & 0.80 & \begin{tabular}{|l}
99.22 \\
\end{tabular} \\
\hline 7 & 55.09 & 1.66 & 14.62 & 10.56 & 0.16 & 3.07 & 4.89 & 5.66 & 1.10 & 0.53 & 1.06 & 98.41 \\
\hline 8 & 50.80 & 1.18 & 13.09 & 11.81 & 0.19 & 7.73 & 8.53 & 2.48 & 0.72 & 0.13 & 1.56 & \begin{tabular}{|l|}
98.22 \\
\end{tabular} \\
\hline 9 & 43.38 & 0.61 & 7.46 & 12.25 & 0.20 & 22.14 & 8.04 & 0.55 & 0.03 & 0.04 & 3.23 & \begin{tabular}{|l}
97.93 \\
\end{tabular} \\
\hline 10 & 43.38 & 0.61 & 7.46 & 12.25 & 0.20 & 22.14 & 8.04 & 0.55 & 0.03 & 0.04 & 3.23 & \begin{tabular}{|l}
97.93 \\
\end{tabular} \\
\hline 11 & 49.58 & 1.03 & 12.25 & 11.32 & 0.19 & 10.18 & 9.96 & 2.56 & 0.30 & 0.12 & 1.00 & \begin{tabular}{|l|}
98.49 \\
\end{tabular} \\
\hline
\end{tabular}

При мечание.1 - дайка диорит-порфира (16399), 2 -3 - дайка плагио-порфира (40301a), 4 - лейкогранит (n=4) Кирьявалахтинского выступа, 5-6 - вулканокластическая граувакка (40301 в, 6703), 7 - средний (n=9) состав трахиандезибазальтов свиты харлу, 8 - средний (n=7) состав базальтов питкярантской свиты, 9-11 -вулканиты свиты тенъярви (9 - коматииты, n=9; 10 - коматиитовые базальты, n=14; 11 - базальты, n=12) 
Таблица 2. Результаты U-Th-Pb геохронологических исследований циркона из лейкогранитов Кирьявалахтинского выступа

\begin{tabular}{|c|c|c|c|c|c|c|c|c|c|c|c|c|c|c|c|c|c|}
\hline \multirow{2}{*}{\multicolumn{2}{|c|}{ 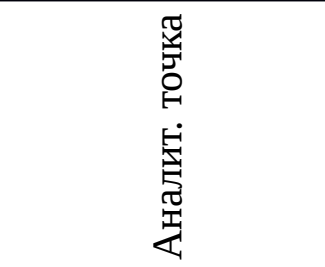 }} & \multirow[b]{2}{*}{$\begin{array}{l}\frac{5}{5} \\
\frac{5}{\Sigma} \\
\emptyset\end{array}$} & \multirow[b]{2}{*}{$\begin{array}{l}\vec{E} \\
\stackrel{5}{\mathbf{E}} \\
\vec{E}\end{array}$} & \multirow[b]{2}{*}{$\stackrel{?}{E}$} & \multirow[b]{2}{*}{ 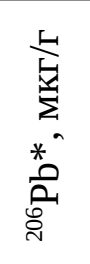 } & \multirow[b]{2}{*}{ 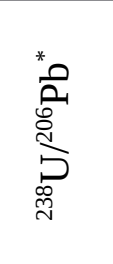 } & \multirow[b]{2}{*}{$\begin{array}{l}\stackrel{0}{+} \\
+1\end{array}$} & \multirow[b]{2}{*}{ 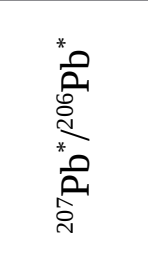 } & \multirow[b]{2}{*}{$\begin{array}{l}\partial^{\circ} \\
++1\end{array}$} & \multirow[b]{2}{*}{ 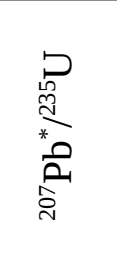 } & \multirow[b]{2}{*}{$\begin{array}{l}\text { oे } \\
+1\end{array}$} & \multicolumn{4}{|c|}{ Возраст } & \multirow[b]{2}{*}{ 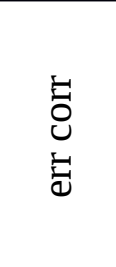 } & \multirow[b]{2}{*}{$\begin{array}{l}0 \\
\text { o } \\
\text { aे }\end{array}$} \\
\hline & & & & & & & & & & & & 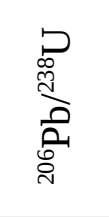 & $\begin{array}{l}0 \\
\text { +1 }\end{array}$ & 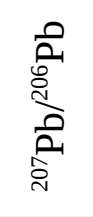 & $\stackrel{\circ}{\circ}+{ }_{+1}$ & & \\
\hline 83003b.5.3 & \multirow{10}{*}{ 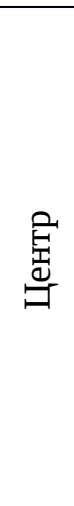 } & 149 & 118 & 0.79 & 71.1 & 1.798 & 0.84 & 0.1904 & 0.83 & 14.60 & 1.2 & 2855 & 21 & 2745 & 14 & 0.710 & -4 \\
\hline 83003b.1.2 & & 59 & 37 & 0.63 & 26.8 & 1.899 & 1.4 & 0.1869 & 1.2 & 13.57 & 1.8 & 2733 & 32 & 2715 & 21 & 0.735 & 0 \\
\hline 83003b.2.2 & & 265 & 130 & 0.49 & 116 & 1.972 & 0.81 & 0.1858 & 0.63 & 13.00 & 1.0 & 2643 & 19 & 2706 & 10 & 0.789 & 2 \\
\hline 83003b.3.3 & & 37 & 18 & 0.49 & 17.5 & 1.853 & 1.6 & 0.1845 & 2.1 & 13.73 & 2.6 & 2804 & 37 & 2694 & 34 & 0.601 & -3 \\
\hline 83003b.4.3 & & 340 & 156 & 0.46 & 150 & 1.949 & 1.1 & 0.18416 & 0.49 & 13.02 & 1.2 & 2671 & 26 & 2690 & 8 & 0.921 & 1 \\
\hline 83003b.6.2 & & 326 & 112 & 0.34 & 146 & 1.917 & 0.64 & 0.18332 & 0.48 & 13.19 & 0.8 & 2708 & 15 & 2683 & 8 & 0.799 & -1 \\
\hline 83003b.4.4 & & 538 & 51 & 0.09 & 233 & 1.938 & 1.2 & 0.18326 & 0.47 & 12.52 & 2.0 & 2632 & 40 & 2655 & 12 & 0.928 & 1 \\
\hline $2018-7.1$ & & 53 & 45 & 0.85 & 23.4 & 1.951 & 0.75 & 0.18706 & 0.4 & 12.68 & 2.8 & 2674 & 50 & 2643 & 27 & 0.810 & -1 \\
\hline $2018-8.1$ & & 253 & 30 & 0.12 & 99.4 & 1.943 & 0.85 & 0.18906 & 0.51 & 11.12 & 1.8 & 2425 & 36 & 2619 & 13 & 0.906 & 9 \\
\hline $2018-9.1$ & & 29 & 31 & 1.07 & 12.9 & 2.067 & 0.74 & 0.18558 & 0.43 & 12.44 & 4.2 & 2685 & 78 & 2606 & 38 & 0.837 & -3 \\
\hline 2018-3.1 & \multirow{6}{*}{ 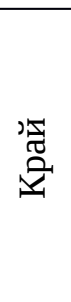 } & 969 & 77 & 0.08 & 381 & 2.036 & 0.87 & 0.1853 & 0.79 & 11.07 & 0.7 & 2426 & 12 & 2601 & 6 & 0.860 & 7 \\
\hline 2018- 2.1 & & 55 & 60 & 1.09 & 23.3 & 2.054 & 1.4 & 0.1671 & 2.0 & 11.21 & 2.5 & 2569 & 34 & 2528 & 34 & 0.578 & -1 \\
\hline 2018_1.1 & & 51 & 155 & 3.04 & 21.2 & 2.112 & 1.7 & 0.1641 & 2.12 & 10.71 & 2.7 & 2453 & 57 & 2498 & 35 & 0.625 & 0 \\
\hline $83003 b .5 .2$ & & 133 & 165 & 1.24 & 53 & 2.151 & 2.0 & 0.1608 & 0.13 & 10.31 & 2.2 & 2463 & 51 & 2465 & 18 & 0.885 & 0 \\
\hline 83003b.4.2 & & 90 & 98 & 1.09 & 35.8 & 2.111 & 1.4 & 0.1593 & 0.72 & 10.25 & 2.5 & 2454 & 40 & 2464 & 23 & 0.835 & 1 \\
\hline 83003b.3.2 & & 509 & 88 & 0.17 & 180 & 2.438 & 0.57 & 0.16014 & 0.51 & 9.058 & 0.8 & 2210 & 11 & 2457 & 8 & 0.749 & 11 \\
\hline
\end{tabular}

- Примечание. Звездочкой отмечены изотопные отношения, исправленные на измеренный ${ }^{204} \mathrm{~Pb}$. Погрешности определения изотопных

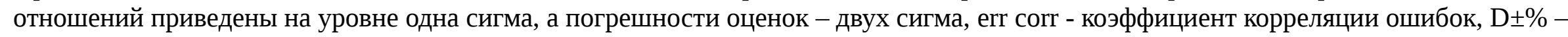
процент дискордантности. 
Таблица 3. Содержание (мкг/г) редкоземельных и редких элементов в цирконе из лейкогранитов Кирьявалахтинского выступа

\begin{tabular}{|l|c|l|l|l|c|c|}
\hline & центр & центр & край & край & край & край \\
\hline & $83003 b .5 .2$ & $83003 b .3 .2$ & $83003 b .3 .1$ & $83003 b .4 .1$ & $83003 b .5 .1$ & $2018-1.1$ \\
\hline $\mathrm{La}$ & 0.73 & 0.49 & 51.2 & 87.4 & 166.8 & 1256.2 \\
\hline $\mathrm{Ce}$ & 21.0 & 14.3 & 331.5 & 514.4 & 673.5 & 2108.1 \\
\hline $\mathrm{Nd}$ & 9.6 & 2.9 & 425.8 & 709.5 & 704.8 & 1015.5 \\
\hline $\mathrm{Eu}$ & 1.5 & 0.5 & 95.2 & 120.0 & 58.5 & 69.3 \\
\hline $\mathrm{Gd}$ & 13.9 & 4.5 & 377.8 & 306.4 & 341.7 & 423.4 \\
\hline $\mathrm{Dy}$ & 34.1 & 15.4 & 331.5 & 257.0 & 256.2 & 269.9 \\
\hline $\mathrm{Er}$ & 76.1 & 37.3 & 290.7 & 209.0 & 213.2 & 277.2 \\
\hline $\mathrm{Yb}$ & 203 & 127 & 588 & 359 & 355 & 524 \\
\hline $\mathrm{Y}$ & 448 & 847 & 1682 & 1586 & 1496 & 1819 \\
\hline $\mathrm{Hf}$ & 7908 & 8990 & 1098 & 1059 & 1018 & 9610 \\
\hline $\mathrm{Ce} / \mathrm{Ce}$ & 2,85 & 5,52 & 0,94 & 0,87 & 0,98 & 0,91 \\
\hline $\mathrm{Eu} / \mathrm{Eu}$ & 0,46 & 0,56 & 0,85 & 0,96 & 0,45 & 0,51 \\
\hline$(\mathrm{Sm} / \mathrm{Yb})_{\mathrm{N}}$ & 0.04 & 0.02 & 0.56 & 1.30 & 1.34 & 0.83 \\
\hline$(\mathrm{La} / \mathrm{Gd})_{\mathrm{N}}$ & 0.04 & 0.09 & 0.11 & 0.24 & 0.41 & 2.49 \\
\hline
\end{tabular}


Таблица 4. Результаты Sm-Nd изотопного анализа

\begin{tabular}{|c|c|c|c|c|c|c|c|c|c|c|}
\hline & 1 & 2 & 3 & 4 & 5 & 6 & 7 & 8 & 9 & 10 \\
\hline № обр. & 830036 & 40301a & 16399 & $72900 \Gamma$ & 143399 & $78800 \mathrm{e}$ & 72900д & 72900 в & $40401 \mathrm{a}$ & $32799 a$ \\
\hline $\mathrm{Sm}, \mathrm{MКг/Г}$ & 3.394 & 0.991 & 2.707 & 4.61 & 3.65 & 4.35 & 3.34 & 4.52 & 2.95 & 2.99 \\
\hline $\mathrm{Nd}, \mathrm{MКг/ \Gamma}$ & 26.51 & 5.163 & 12.1 & 22.63 & 15.59 & 21.18 & 15.21 & 20.59 & 9.06 & 11.24 \\
\hline${ }^{147} \mathrm{Sm} /{ }^{144} \mathrm{Nd}$ & 0.0774 & 0.116 & 0.1249 & 0.1232 & 0.1433 & 0.124 & 0.1327 & 0.1328 & 0.1965 & 0.1608 \\
\hline${ }^{143} \mathrm{Nd} /{ }^{144} \mathrm{Nd}$ & 0.51058 & 0.51137 & 0.5116 & 0.51143 & 0.51013 & 0.51146 & 0.51159 & 0.51154 & 0.51243 & 0.51211 \\
\hline$\varepsilon N d(T)$ & 1.5 & -4.8 & -2.6 & -5.11 & -4.01 & -4.77 & -4.3 & -5.38 & -4.01 & -1.37 \\
\hline \multirow[t]{2}{*}{ T DM } & 2865 & 2796 & 2612 & 2885 & & 2864 & 2917 & 3021 & & \\
\hline & 10 & 11 & 12 & 13 & 14 & 15 & 16 & 17 & 18 & 19 \\
\hline № обр. & $32799 a$ & 32999ж & 13399д & 12899 & 88500 & 67500 & 62400в & $40501 a$ & $41001 \Gamma$ & 41501 \\
\hline Sm, мКг/Г & 2.99 & 2.34 & 1.83 & 2.09 & 2.67 & 2.29 & 1.45 & 3.55 & 1.67 & 1.67 \\
\hline $\mathrm{Nd}, \mathrm{мКг/ \Gamma}$ & 11.24 & 8.68 & 5.83 & 4.35 & 9.79 & 7.79 & 3.66 & 16.17 & 4.7 & 4.64 \\
\hline${ }^{147} \mathrm{Sm} /{ }^{144} \mathrm{Nd}$ & 0.1608 & 0.1629 & 0.1902 & 0.2907 & 0.1648 & 0.1777 & 0.2387 & 0.1326 & 0.2144 & 0.218 \\
\hline${ }^{143} \mathrm{Nd} /{ }^{144} \mathrm{Nd}$ & 0.51211 & 0.51214 & 0.51265 & 0.51388 & 0.5123 & 0.51246 & 0.51321 & 0.51188 & 0.51307 & 0.51313 \\
\hline$\varepsilon N d(T)$ & -1.37 & -1.18 & 1.78 & 0.63 & 1.42 & 1.39 & 0.49 & 1.41 & 4.03 & 4.28 \\
\hline T DM & & & & & & & & 2375 & & \\
\hline
\end{tabular}

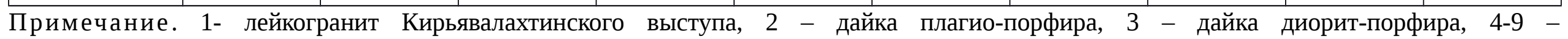

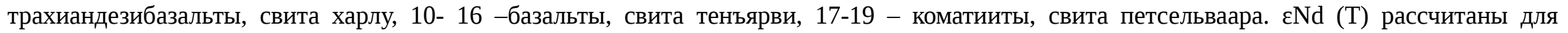

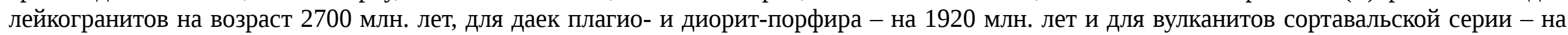
1960 млн. лет 
Таблица 5. Результаты U-Th-Pb геохронологических исследований циркона из граувакк сортавальской серии

\begin{tabular}{|c|c|c|c|c|c|c|c|c|c|c|c|c|c|c|c|c|c|}
\hline \multirow[b]{2}{*}{$\begin{array}{l}\text { 目 } \\
\text { 呪 }\end{array}$} & \multirow{2}{*}{ 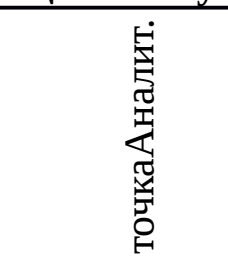 } & \multirow[b]{2}{*}{$\begin{array}{l}\frac{5}{5} \\
\frac{5}{5} \\
\vdots\end{array}$} & \multirow[b]{2}{*}{$\underset{⿱ 亠 䒑}{\mid}$} & \multirow[b]{2}{*}{$\stackrel{?}{E}$} & \multirow[b]{2}{*}{ 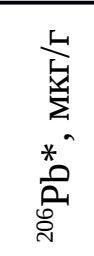 } & \multirow[b]{2}{*}{ 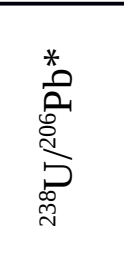 } & \multirow[b]{2}{*}{$\stackrel{े}{+1}^{\circ}$} & \multirow{2}{*}{ 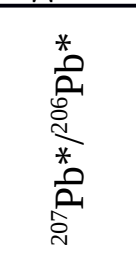 } & \multirow[b]{2}{*}{$\stackrel{\circ}{\circ}$} & \multirow[b]{2}{*}{ 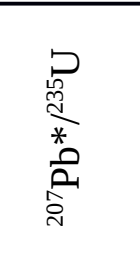 } & \multirow[b]{2}{*}{$\stackrel{\circ}{\circ}$} & \multicolumn{4}{|c|}{ Возраст } & \multirow[b]{2}{*}{$\begin{array}{l}5 \\
0 \\
0 \\
\overline{0}\end{array}$} & \multirow[b]{2}{*}{$\begin{array}{l}\stackrel{0}{\circ} \\
\stackrel{+1}{0}\end{array}$} \\
\hline & & & & & & & & & & & & 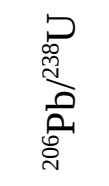 & 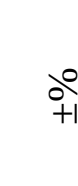 & $\begin{array}{l}\hat{0} \\
\text { 离 } \\
\text { 今े }\end{array}$ & $\begin{array}{l}\partial_{0}^{\circ} \\
+1\end{array}$ & & \\
\hline 1 & 40301в.2.1 & 82 & 80 & 0.98 & 0.47 & $\begin{array}{r}3.218 \\
3 \\
\end{array}$ & $\begin{array}{r}1 . \\
5\end{array}$ & 0.1147 & 2.9 & 4.912 & 3.2 & 1744 & 23 & 1875 & 52 & 0.461 & 7 \\
\hline 2 & 40301в.13.1 & 217 & 74 & 0.34 & 0.25 & $\begin{array}{r}2.667 \\
6\end{array}$ & $\begin{array}{r}1 . \\
1\end{array}$ & 0.1201 & 1.5 & 6.207 & 1.9 & 2052 & 20 & 1958 & 17 & 0.598 & -5 \\
\hline 3 & 40301в.12.1 & 492 & 213 & 0.43 & 0.18 & $\begin{array}{r}2.229 \\
7\end{array}$ & $\begin{array}{r}1 . \\
0\end{array}$ & 0.1836 & 0.6 & 11.352 & 1.1 & 2388 & 20 & 2685 & 10 & 0.856 & 10 \\
\hline 4 & 40301в.3.1 & 245 & 208 & 0.85 & 0.56 & $\begin{array}{r}2.175 \\
9 \\
\end{array}$ & $\begin{array}{r}1 . \\
0\end{array}$ & 0.1800 & 1.1 & 11.404 & 1.5 & 2438 & 21 & 2653 & 17 & 0.704 & 9 \\
\hline 5 & 40301в.4.1 & 349 & 157 & 0.45 & 0.32 & $\begin{array}{r}2.172 \\
2 \\
\end{array}$ & $\begin{array}{r}1 . \\
0\end{array}$ & 0.1802 & 0.7 & 11.441 & 1.3 & 2441 & 21 & 2655 & 12 & 0.814 & 9 \\
\hline 6 & 40301в.6.1 & 987 & 125 & 0.13 & 0.06 & $\begin{array}{r}2.142 \\
4 \\
\end{array}$ & $\begin{array}{r}0 . \\
9 \\
\end{array}$ & 0.1932 & 0.4 & 12.435 & 1.0 & 2469 & 19 & 2770 & 7 & 0.916 & 12 \\
\hline 7 & 40301в.9.1 & 372 & 231 & 0.62 & 0.21 & $\begin{array}{r}2.094 \\
6 \\
\end{array}$ & $\begin{array}{r}1 . \\
0 \\
\end{array}$ & 0.2009 & 0.7 & 13.222 & 1.2 & 2516 & 20 & 2833 & 12 & 0.802 & 13 \\
\hline 8 & 40301в.8.1 & 283 & 292 & 1.03 & 0.01 & $\begin{array}{r}2.000 \\
1 \\
\end{array}$ & $\begin{array}{r}1 . \\
0 \\
\end{array}$ & 0.1880 & 0.7 & 12.963 & 1.2 & 2614 & 22 & 2725 & 11 & 0.838 & 4 \\
\hline 9 & 40301в.14.1 & 286 & 30 & 0.11 & 0.08 & $\begin{array}{r}1.963 \\
0 \\
\end{array}$ & $\begin{array}{r}1 . \\
1\end{array}$ & 0.1848 & 0.7 & 12.984 & 1.3 & 2654 & 24 & 2697 & 12 & 0.840 & 2 \\
\hline 10 & 40301в.10.1 & 491 & 92 & 0.19 & 0.04 & $\begin{array}{r}1.961 \\
2\end{array}$ & $\begin{array}{r}0 . \\
9\end{array}$ & 0.2013 & 0.5 & 14.152 & 1.0 & 2656 & 20 & 2837 & 8 & 0.886 & 7 \\
\hline 11 & 40301в.11.1 & 167 & 104 & 0.62 & 0.15 & $\begin{array}{r}1.946 \\
6\end{array}$ & $\begin{array}{r}1 . \\
4\end{array}$ & 0.1920 & 1.2 & 13.596 & 1.9 & 2672 & 31 & 2759 & 20 & 0.764 & 3 \\
\hline 12 & 40301в.5.1 & 185 & 83 & 0.45 & 0.39 & $\begin{array}{r}1.934 \\
7 \\
\end{array}$ & $\begin{array}{r}1 . \\
1\end{array}$ & 0.1901 & 1.0 & 13.551 & 1.5 & 2686 & 25 & 2743 & 16 & 0.748 & 2 \\
\hline 13 & 40301в.5.2 & 284 & 108 & 0.38 & 0.19 & $\begin{array}{r}1.934 \\
6 \\
\end{array}$ & $\begin{array}{r}1 . \\
0\end{array}$ & 0.1860 & 0.8 & 13.258 & 1.3 & 2686 & 23 & 2707 & 13 & 0.799 & 1 \\
\hline
\end{tabular}




\begin{tabular}{|c|c|c|c|c|c|c|c|c|c|c|c|c|c|c|c|c|c|}
\hline 14 & 40301-18-15.1 & 417 & 233 & 0.56 & 0.03 & $\begin{array}{r}1.942 \\
0\end{array}$ & $\begin{array}{r}1 . \\
9\end{array}$ & 0.1901 & 3.5 & 13.562 & 1.0 & 2707 & 19 & 2728 & 9 & 0.830 & 1 \\
\hline 15 & 40301-18-16.1 & 697 & 569 & 0.82 & 0.15 & $\begin{array}{r}1.936 \\
0\end{array}$ & $\begin{array}{r}1 . \\
3\end{array}$ & 0.1897 & 0.5 & 13.343 & 0.9 & 2710 & 16 & 2699 & 8 & 0.835 & 0 \\
\hline 16 & 40301-18-17.1 & 546 & 428 & 0.78 & 0.30 & $\begin{array}{r}1.931 \\
0\end{array}$ & $\begin{array}{r}1 . \\
4\end{array}$ & 0.1882 & 0.4 & 11.120 & 1.1 & 2361 & 16 & 2672 & 13 & 0.729 & 13 \\
\hline 17 & 40301-18-17.2 & 381 & 119 & 0.31 & 0.23 & $\begin{array}{r}2.768 \\
5\end{array}$ & $\begin{array}{r}1 . \\
1\end{array}$ & 0.1168 & 1.5 & 6.0812 & 1.5 & 1977 & 15 & 1973 & 21 & 0.613 & 0 \\
\hline 18 & 6703.7 .1 & 2074 & 91 & 0.04 & 0.08 & 1.797 & $\begin{array}{r}0 . \\
8\end{array}$ & 0.2381 & 0.2 & 18.293 & 0.9 & 2852 & 19 & 3110 & 3 & 0.968 & 9 \\
\hline 19 & 6703.7 .2 & 1410 & 294 & 0.21 & 0.60 & 1.682 & $\begin{array}{r}0 . \\
9\end{array}$ & 0.2474 & 0.3 & 20.224 & 0.9 & 3008 & 21 & 3164 & 5 & 0.937 & 5 \\
\hline 20 & $6703-18-9.1$ & 141 & 86 & 0.61 & 2.45 & 3.227 & $\begin{array}{r}2 . \\
5\end{array}$ & 0.1105 & 2.9 & 4.680 & 3.8 & 1744 & 3 & 1801 & 52 & 0.661 & 4 \\
\hline
\end{tabular}

- Примечание. Звездочкой отмечены изотопные отношения, исправленные на измеренный ${ }^{204}$ Рb. Погрешности определения изотопных отношений приведены на уровне одна сигма, а погрешности оценок - двух сигма, егr согr - коэффициент корреляции ошибок, D£\% - процент дискордантности. 
Таблица 6. Содержание (мкг/г) редкоземельных элементов в цирконе из граувакк питкярантской свиты (40318в и 6703)

\begin{tabular}{|c|c|c|c|c|c|c|c|c|c|c|}
\hline & 12.1 & 10.1 & 3.1 & 6.1 & 14.1 & 5.2 & 9.1 & 8.1 & 2.1 & $9.1 / 18$ \\
\hline $\mathrm{La}$ & 12.74 & 0.27 & 7.18 & 3.63 & 1.97 & 1.37 & 6.17 & 2.60 & 51.22 & 75.37 \\
\hline $\mathrm{Ce}$ & 98.28 & 10.70 & 112.62 & 37.28 & 8.50 & 8.77 & 56.73 & 65.09 & 5 & 6 \\
\hline & & & & & & & & & 425.7 & 671.3 \\
$\mathrm{Nd}$ & 86.06 & 1.28 & 44.79 & 30.73 & 6.74 & 3.97 & 53.15 & 18.09 & 8 & 3 \\
\hline & & & & & & & & & 305.3 & 312.3 \\
$\mathrm{Sm}$ & 56.30 & 1.98 & 32.52 & 20.09 & 4.82 & 4.05 & 39.08 & 15.68 & 0 & 8 \\
\hline $\mathrm{Eu}$ & 8.07 & 0.44 & 3.32 & 5.34 & 0.39 & 1.15 & 6.72 & 2.01 & 95.18 & 65.84 \\
\hline & 103.4 & & & & & & & & 377.8 & 377.3 \\
$\mathrm{Gd}$ & 0 & 10.08 & 80.98 & 44.21 & 16.45 & 16.45 & 82.35 & 40.92 & 3 & 3 \\
\hline & 250.4 & & 210.8 & 132.6 & & & 231.1 & 121.4 & 331.5 & 531.9 \\
$\mathrm{Dy}$ & 3 & 48.57 & 9 & 9 & 62.73 & 60.52 & 2 & 1 & 1 & 6 \\
\hline & 286.8 & 127.4 & 307.4 & 320.2 & 153.1 & 130.9 & 379.5 & 203.3 & 290.7 & 290.8 \\
$\mathrm{Er}$ & 2 & 9 & 1 & 8 & 4 & 4 & 4 & 4 & 0 & 2 \\
\hline & 436.6 & 302.8 & 513.8 & 668.4 & 453.4 & 270.2 & 641.4 & 347.6 & 588.0 & 338.2 \\
$\mathrm{Yb}$ & 5 & 1 & 5 & 1 & 4 & 0 & 5 & 8 & 5 & 2 \\
\hline $\mathrm{Ce} / \mathrm{Ce} *$ & 1.32 & 8.88 & 2.86 & 1.47 & 1.20 & 1.98 & 1.30 & 4.20 & 0.97 & 0.89 \\
\hline $\mathrm{Eu} / \mathrm{Eu} *$ & 0.32 & 0.25 & 0.19 & 0.53 & 0.12 & 0.37 & 0.35 & 0.23 & 0.85 & 0.58 \\
\hline$(\mathrm{Sm} / \mathrm{Yb})_{\mathrm{N}}$ & 0.14 & 0.01 & 0.07 & 0.03 & 0.01 & 0.02 & 0.07 & 0.05 & 0.56 & 1.00 \\
\hline$(\mathrm{La} / \mathrm{Gd})_{\mathrm{N}}$ & 0.10 & 0.02 & 0.07 & 0.07 & 0.10 & 0.07 & 0.06 & 0.05 & 0.11 & 0.17 \\
\hline
\end{tabular}


Таблица 7. Результаты U-Th-Pb геохронологических исследований циркона из трахиандезибазальтов свиты харлу (14399), даек плагио-порфира 40301а и диорит-порфира 16399

\begin{tabular}{|c|c|c|c|c|c|c|c|c|c|c|c|c|c|c|c|c|}
\hline \multirow{2}{*}{ 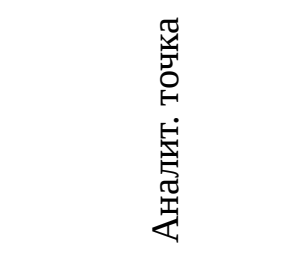 } & \multirow[b]{2}{*}{ 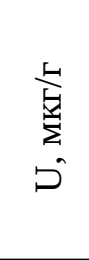 } & \multirow[b]{2}{*}{$\underset{\sum}{E}$} & \multirow[b]{2}{*}{$\sum_{E}$} & \multirow{2}{*}{ 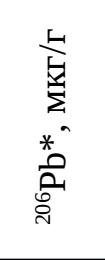 } & \multirow[b]{2}{*}{ 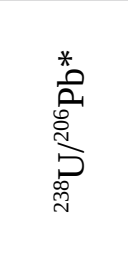 } & \multirow[b]{2}{*}{$\begin{array}{l}\stackrel{0}{+} \\
+1\end{array}$} & \multirow{2}{*}{ 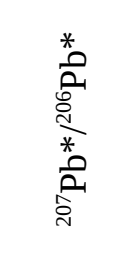 } & \multirow[b]{2}{*}{$\begin{array}{l}\stackrel{0}{+} \\
+1\end{array}$} & \multirow[b]{2}{*}{ 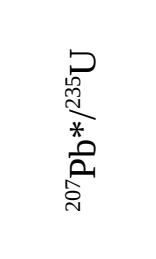 } & \multirow[b]{2}{*}{$\begin{array}{l}\circ \\
+1\end{array}$} & \multicolumn{4}{|c|}{ Возраст } & \multirow[b]{2}{*}{$\begin{array}{l}5 \\
0 \\
\vdots \\
\overline{0}\end{array}$} & \multirow[b]{2}{*}{$\begin{array}{l}\circ \\
\stackrel{+}{+1} \\
0\end{array}$} \\
\hline & & & & & & & & & & & 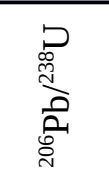 & $\begin{array}{l}\partial^{\circ} \\
+1\end{array}$ & 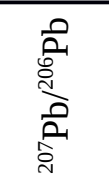 & $\begin{array}{l}\stackrel{0}{\circ} \\
+1\end{array}$ & & \\
\hline 40301а.1.1 центр & 70 & 59 & 0.87 & 32.4 & 1.858 & 2.8 & 0.2001 & 1.2 & 14.8500 & 3.0 & 2800 & 68 & 2827 & 19 & 0.921 & 2 \\
\hline 40301a.1.2 & 101 & 9 & 0.09 & 28.9 & 3.001 & 2.9 & 0.1155 & 3.4 & 5.3100 & 4.5 & 1853 & 47 & 1888 & 61 & 0.657 & 2 \\
\hline 40301a.2.1 & 295 & 26 & 0.09 & 79.1 & 3.214 & 2.7 & 0.1170 & 0.9 & 5.0200 & 2.9 & 1752 & 42 & 1911 & 16 & 0.948 & 9 \\
\hline 16399.1.1.2 & 100 & 92 & 0.94 & 37.3 & 2.413 & 2.8 & 0.1658 & 4.8 & 9.4800 & 5.5 & 2256 & 64 & 2516 & 80 & 0.502 & 11 \\
\hline 16399.3.1 центр & 342 & 48 & 0.15 & 159 & 1.851 & 0.6 & 0.1930 & 0.4 & 14.3800 & 0.7 & 2789 & 15 & 2767 & 7 & 0.806 & -3 \\
\hline 16399.3.2 & 106 & 35 & 0.34 & 36.2 & 2.528 & 0.9 & 0.1416 & 1.3 & 7.7300 & 1.6 & 2145 & 19 & 2247 & 23 & 0.590 & 5 \\
\hline 14399.9 .1 & 71 & 28 & 0.42 & 20.9 & 2.9378 & 1.5 & 0.1123 & 3.8 & 5.2715 & 4.1 & 1889 & 25 & 1837 & 70 & 0.368 & -3 \\
\hline 14399.12 .1 & 367 & 340 & 0.96 & 101.9 & 3.0960 & 1.2 & 0.1186 & 1.3 & 5.2823 & 1.8 & 1804 & 19 & 1935 & 23 & 0.682 & 7 \\
\hline 14399.5.1 & 422 & 165 & 0.40 & 122.0 & 2.9791 & 1.0 & 0.1234 & 0.9 & 5.7102 & 1.3 & 1866 & 16 & 2006 & 16 & 0.727 & 7 \\
\hline 14399.2.1 & 303 & 266 & 0.91 & 86.4 & 3.0299 & 1.0 & 0.1237 & 1.2 & 5.6285 & 1.5 & 1839 & 16 & 2010 & 21 & 0.649 & 9 \\
\hline 14399.4 .1 & 356 & 135 & 0.39 & 96.5 & 3.1788 & 1.0 & 0.1255 & 1.1 & 5.4435 & 1.5 & 1763 & 16 & 2036 & 19 & 0.688 & 15 \\
\hline 14399.8 .1 & 134 & 48 & 0.37 & 41.0 & 3.0370 & 1.5 & 0.1321 & 6.2 & 5.9977 & 6.4 & 1835 & 24 & 2126 & 19 & 0.235 & 16 \\
\hline 14399.10 .1 & 125 & 89 & 0.74 & 54.7 & 1.9727 & 1.2 & 0.1872 & 0.9 & 13.0836 & 1.5 & 2643 & 26 & 2718 & 16 & 0.766 & 3 \\
\hline 14399.11 .1 & 221 & 119 & 0.56 & 95.6 & 1.9919 & 1.1 & 0.1892 & 0.8 & 13.0963 & 1.3 & 2623 & 23 & 2735 & 14 & 0.789 & 4 \\
\hline 14399.6.1 & 178 & 177 & 1.03 & 82.5 & 1.8569 & 1.1 & 0.1946 & 0.8 & 14.4531 & 1.3 & 2777 & 25 & 2782 & 14 & 0.788 & 0 \\
\hline
\end{tabular}

• Примечание. Звездочкой отмечены изотопные отношения, исправленные на измеренный ${ }^{204} \mathrm{~Pb}$. Погрешности определения изотопных

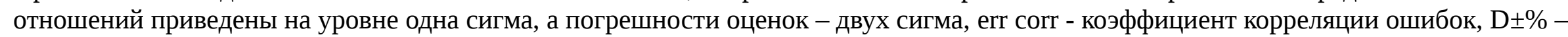
процент дискордантности. 
Таблица 8. Содержание (мкг/г) редкоземельных элементов в цирконе из трахиандезибазальтов свиты харлу (14399), даек плагиопорфира (40301а) и диорит-порфира (16399)

\begin{tabular}{|l|r|r|r|r|r|r|r|r|r|r|}
\hline & \multicolumn{2}{|c|}{16399} & \multicolumn{4}{c|}{$40301 \mathrm{a}$} & \multicolumn{4}{|c|}{14399} \\
\hline & \multicolumn{1}{|c|}{2.1} & 3.2 & $\begin{array}{c}1.1 \\
\text { центр }\end{array}$ & $\begin{array}{c}1.2 \\
\text { край }\end{array}$ & $\begin{array}{c}2.1 \\
\text { центр }\end{array}$ & $\begin{array}{c}2.2 \\
\text { край }\end{array}$ & \multicolumn{1}{|c|}{6.1} & 11.1 & 10.1 & 9.1 \\
\hline $\mathrm{La}$ & 2.63 & 8.32 & 1.10 & 2.05 & 1.15 & 0.50 & 1.15 & 2.82 & 0.20 & 27.21 \\
\hline $\mathrm{Ce}$ & 56.07 & 83.55 & 6.98 & 37.45 & 17.41 & 13.17 & 74.02 & 68.75 & 39.06 & 77.22 \\
\hline $\mathrm{Nd}$ & 41.81 & 44.45 & 3.99 & 32.67 & 8.04 & 5.81 & 13.11 & 40.77 & 2.24 & 56.06 \\
\hline $\mathrm{Sm}$ & 44.83 & 9.07 & 4.32 & 18.89 & 7.22 & 6.85 & 10.75 & 15.49 & 2.00 & 22.68 \\
\hline $\mathrm{Eu}$ & 9.32 & 2.85 & 0.26 & 1.86 & 1.97 & 0.49 & 2.31 & 2.04 & 0.14 & 7.53 \\
\hline $\mathrm{Gd}$ & 89.82 & 10.51 & 13.81 & 22.63 & 27.48 & 24.42 & 30.91 & 29.36 & 9.63 & 46.30 \\
\hline $\mathrm{Dy}$ & 154.77 & 29.03 & 34.68 & 38.28 & 130.62 & 73.14 & 82.82 & 61.42 & 36.69 & 70.49 \\
\hline $\mathrm{Er}$ & 214.01 & 77.72 & 54.12 & 62.72 & 327.12 & 143.97 & 160.36 & 83.73 & 76.48 & 92.66 \\
\hline $\mathrm{Yb}$ & 449.25 & 227.47 & 123.50 & 171.11 & 732.33 & 266.24 & 306.96 & 152.95 & 155.02 & 185.10 \\
\hline $\mathrm{Ce} *$ & 0.45 & 0.51 & 0.43 & 0.38 & 0.63 & 0.72 & 1.80 & 0.55 & 5.55 & 0.27 \\
\hline $\mathrm{Eu} *$ & 0.11 & 0.10 & 0.02 & 0.07 & 0.09 & 0.03 & 0.09 & 0.07 & 0.02 & 0.17 \\
\hline$(\mathrm{Sm} / \mathrm{Yb})_{\mathrm{N}}$ & 0.11 & 0.04 & 0.04 & 0.12 & 0.01 & 0.03 & 0.04 & 0.11 & 0.01 & 0.13 \\
\hline$(\mathrm{La} / \mathrm{Gd})_{\mathrm{N}}$ & 0.02 & 0.66 & 0.07 & 0.07 & 0.03 & 0.02 & 0.03 & 0.08 & 0.02 & 0.49 \\
\hline
\end{tabular}




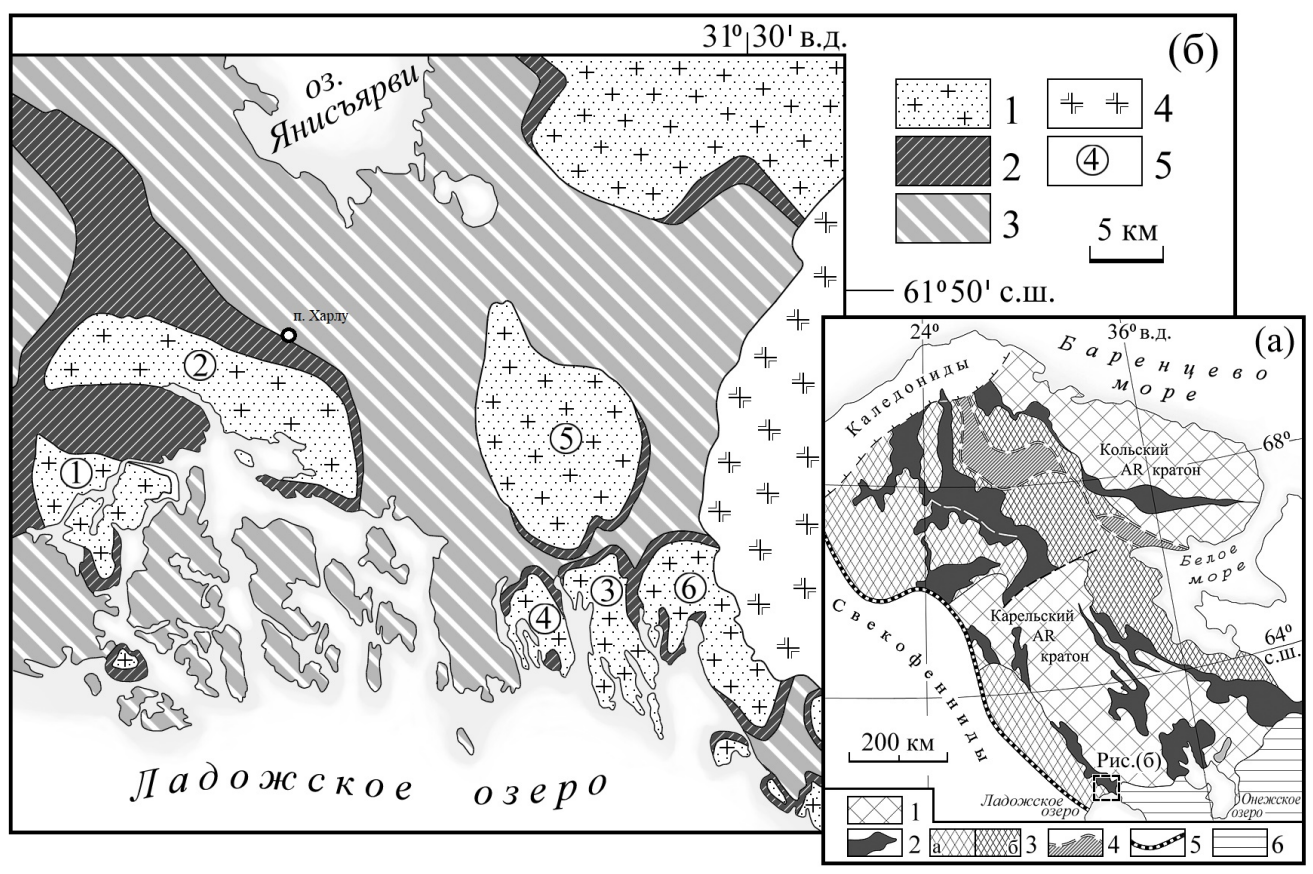




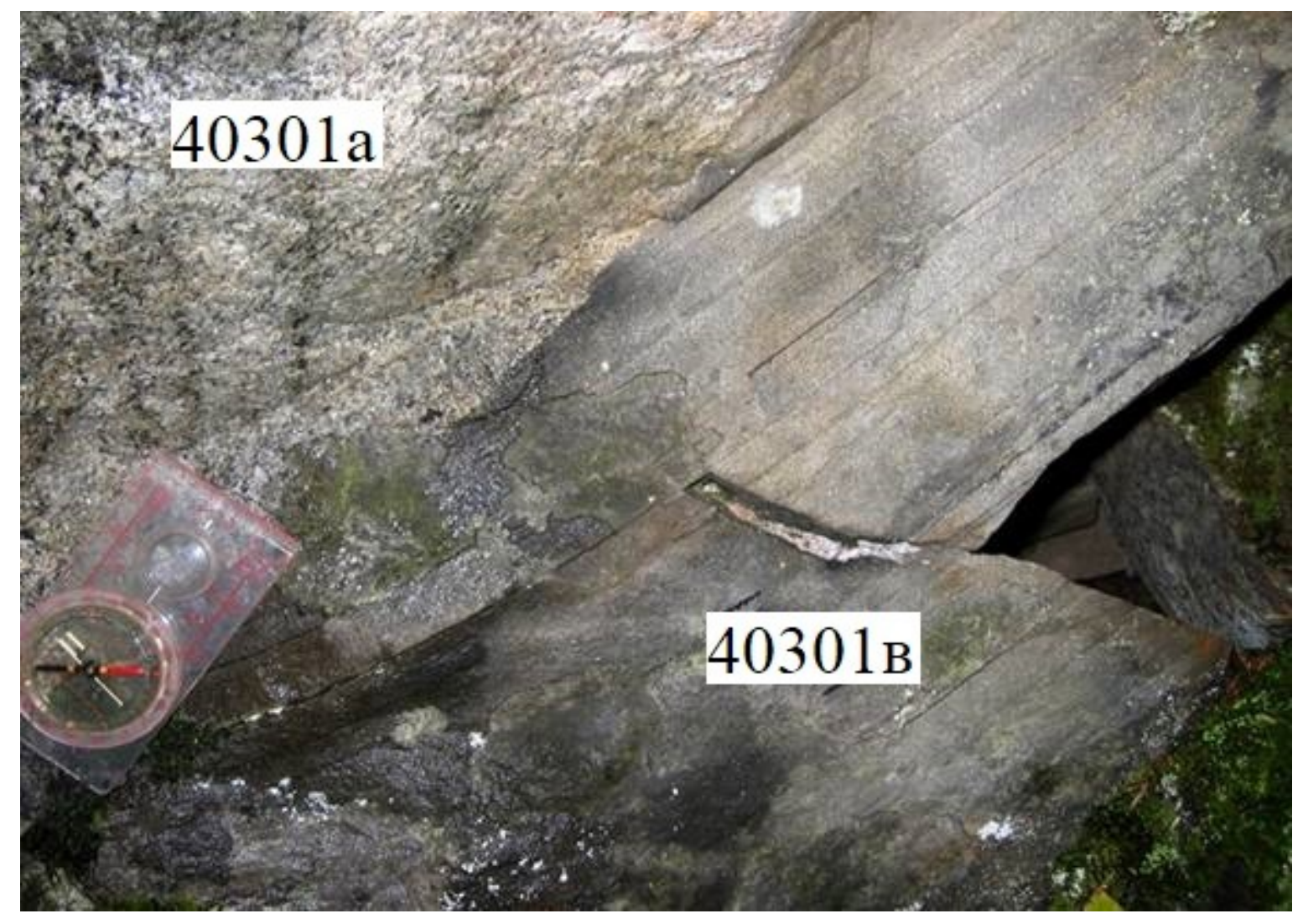




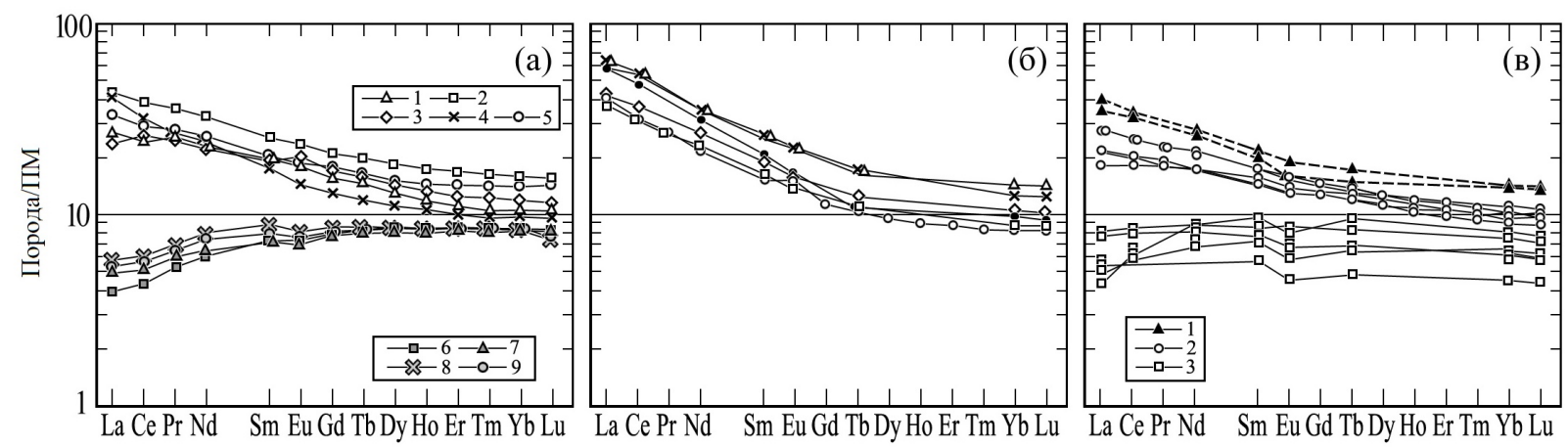




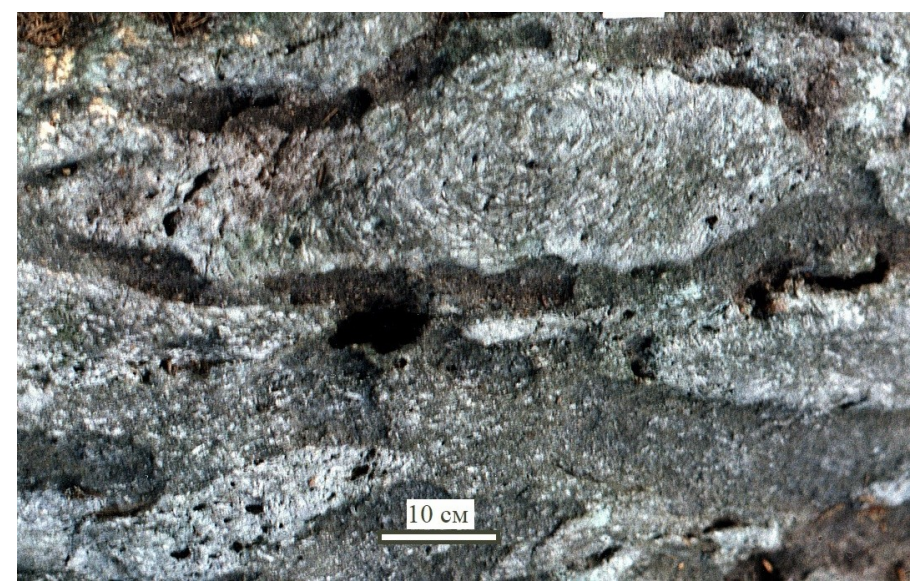




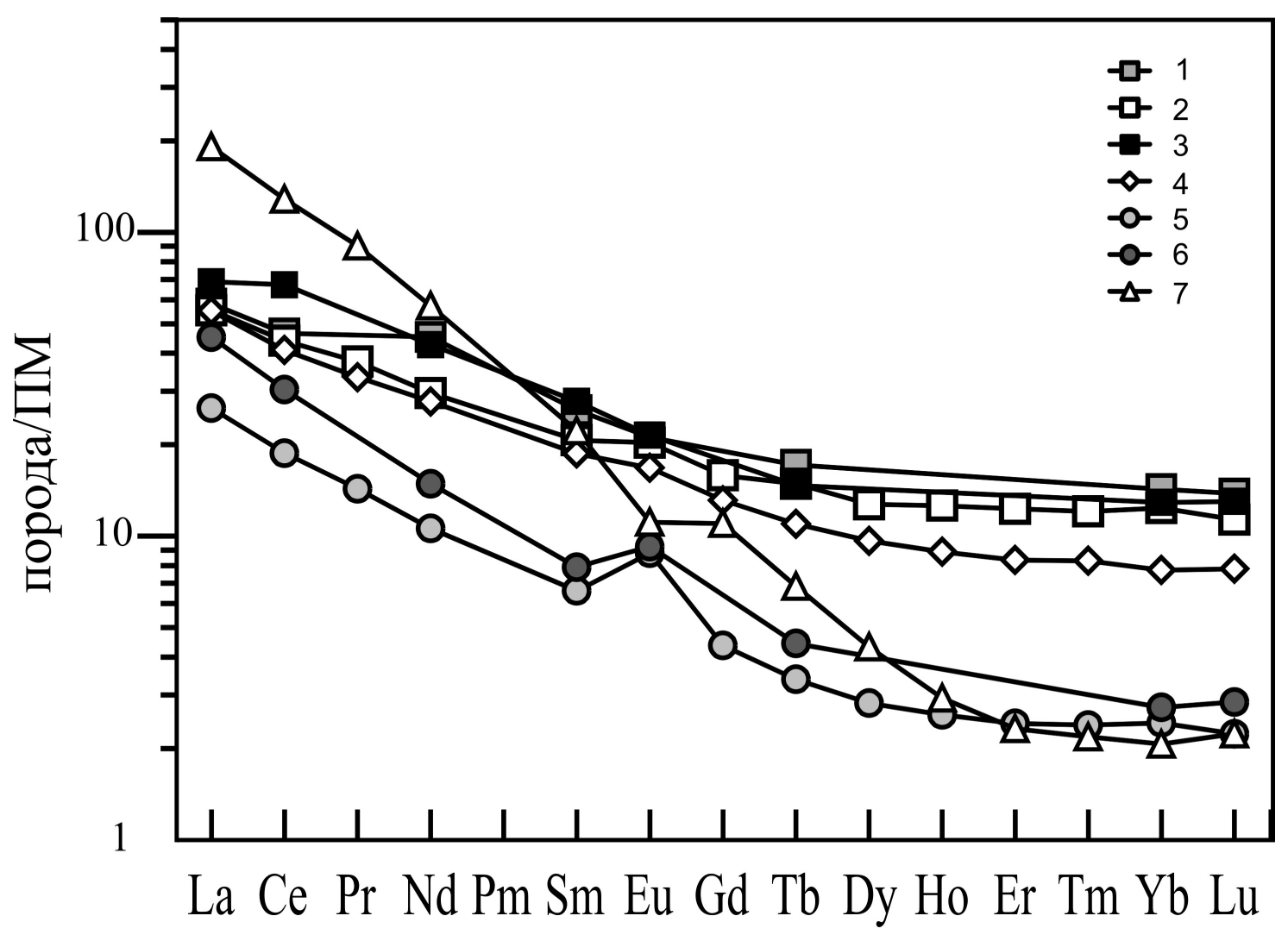




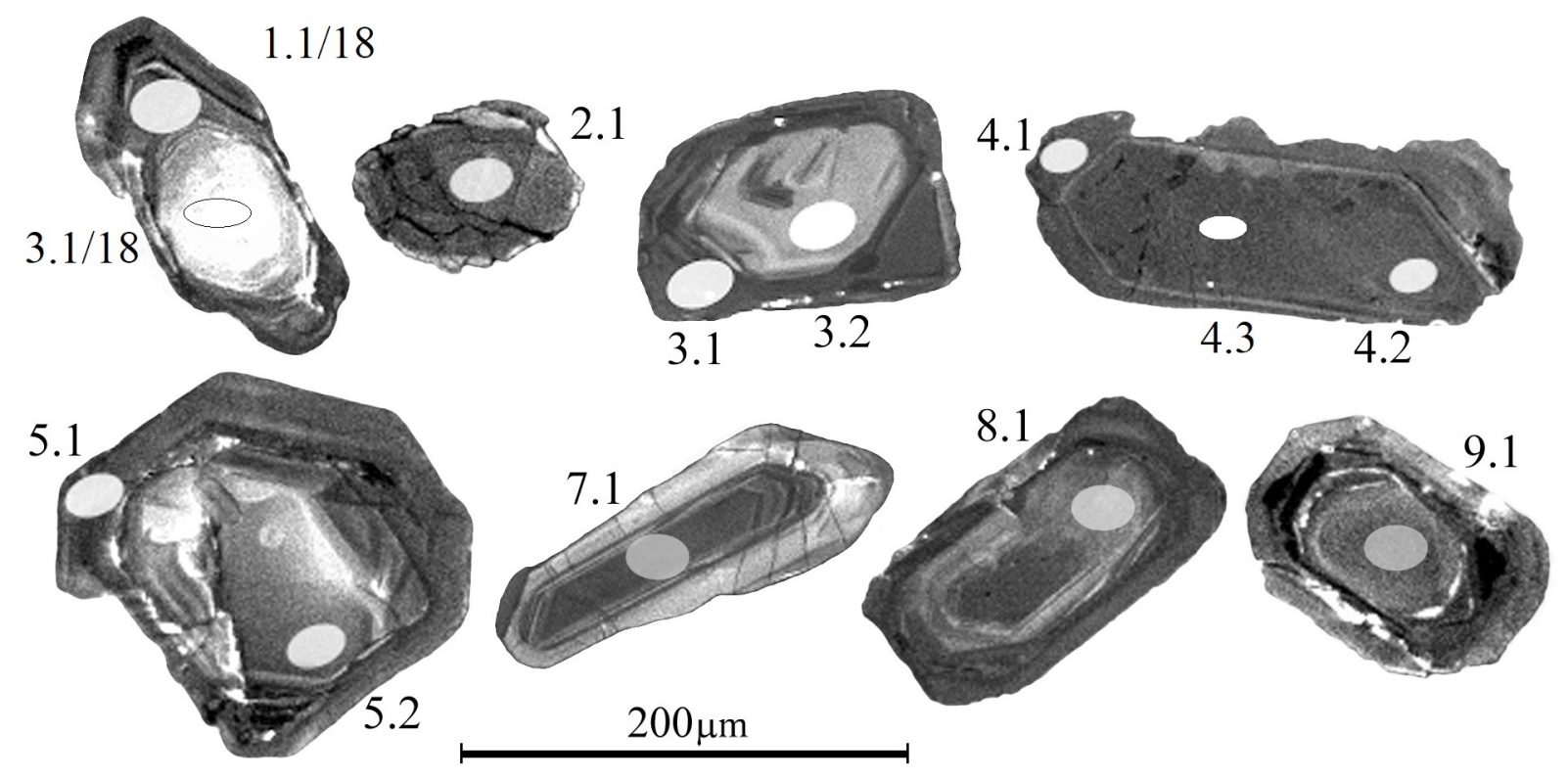



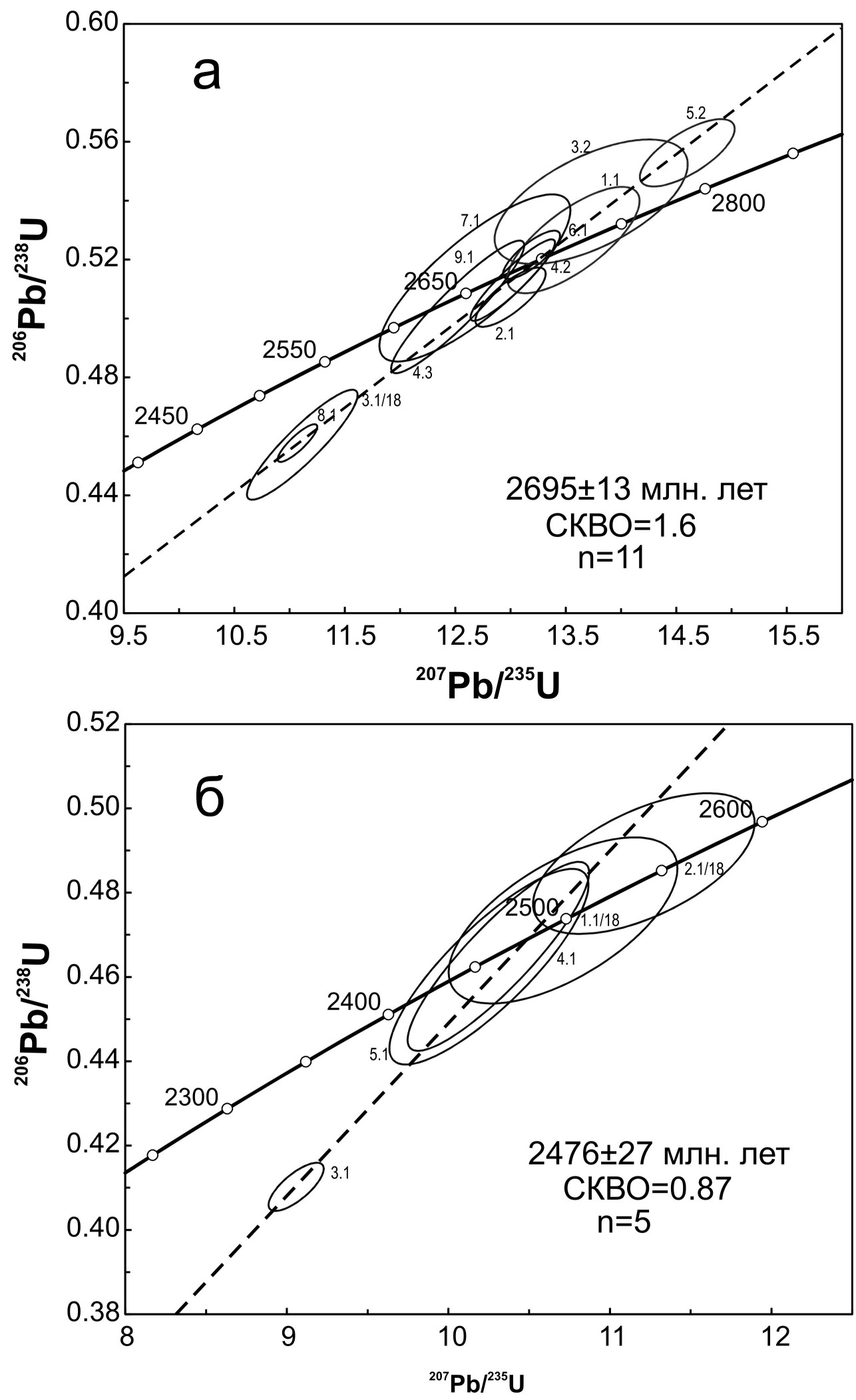


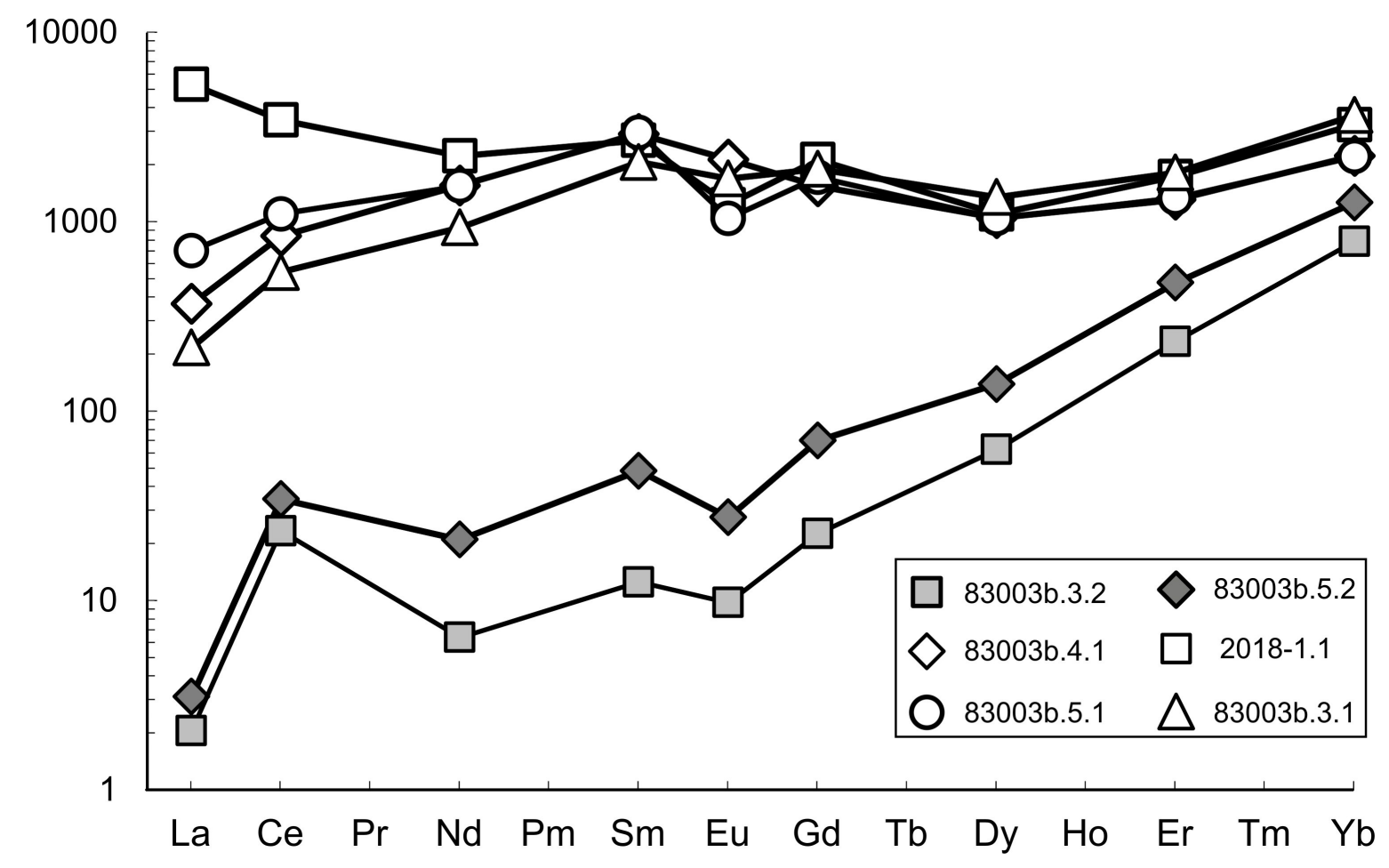




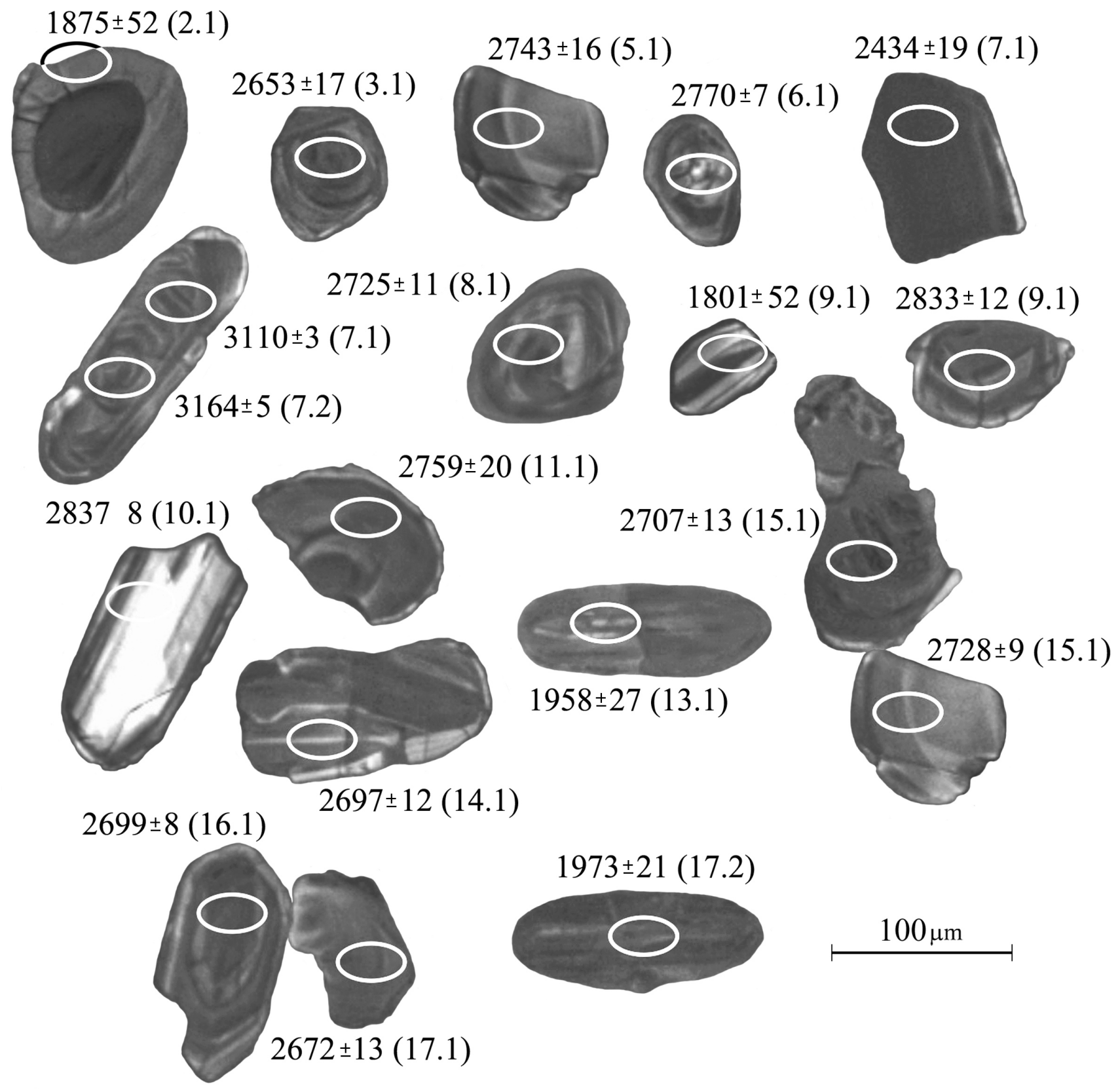



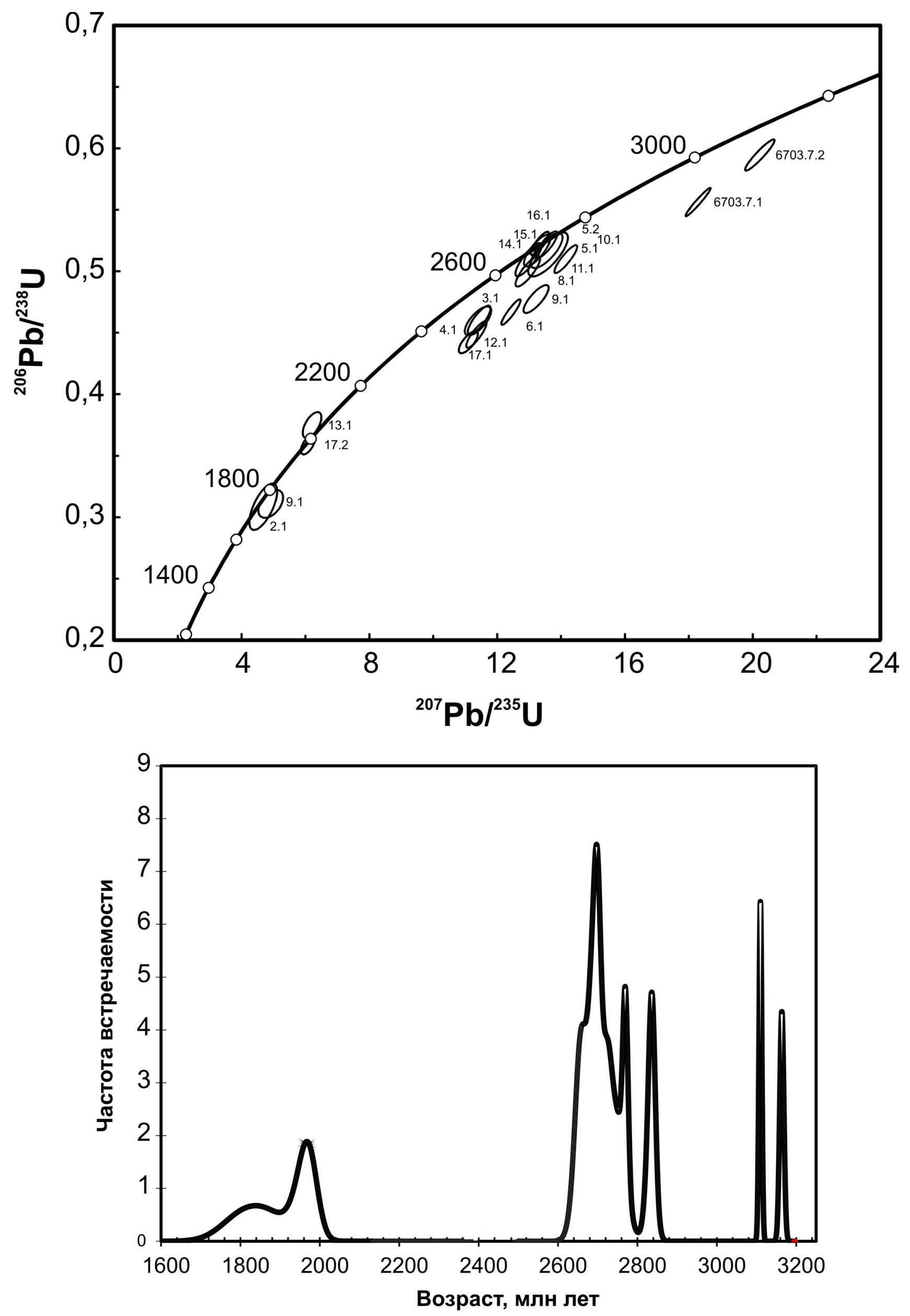


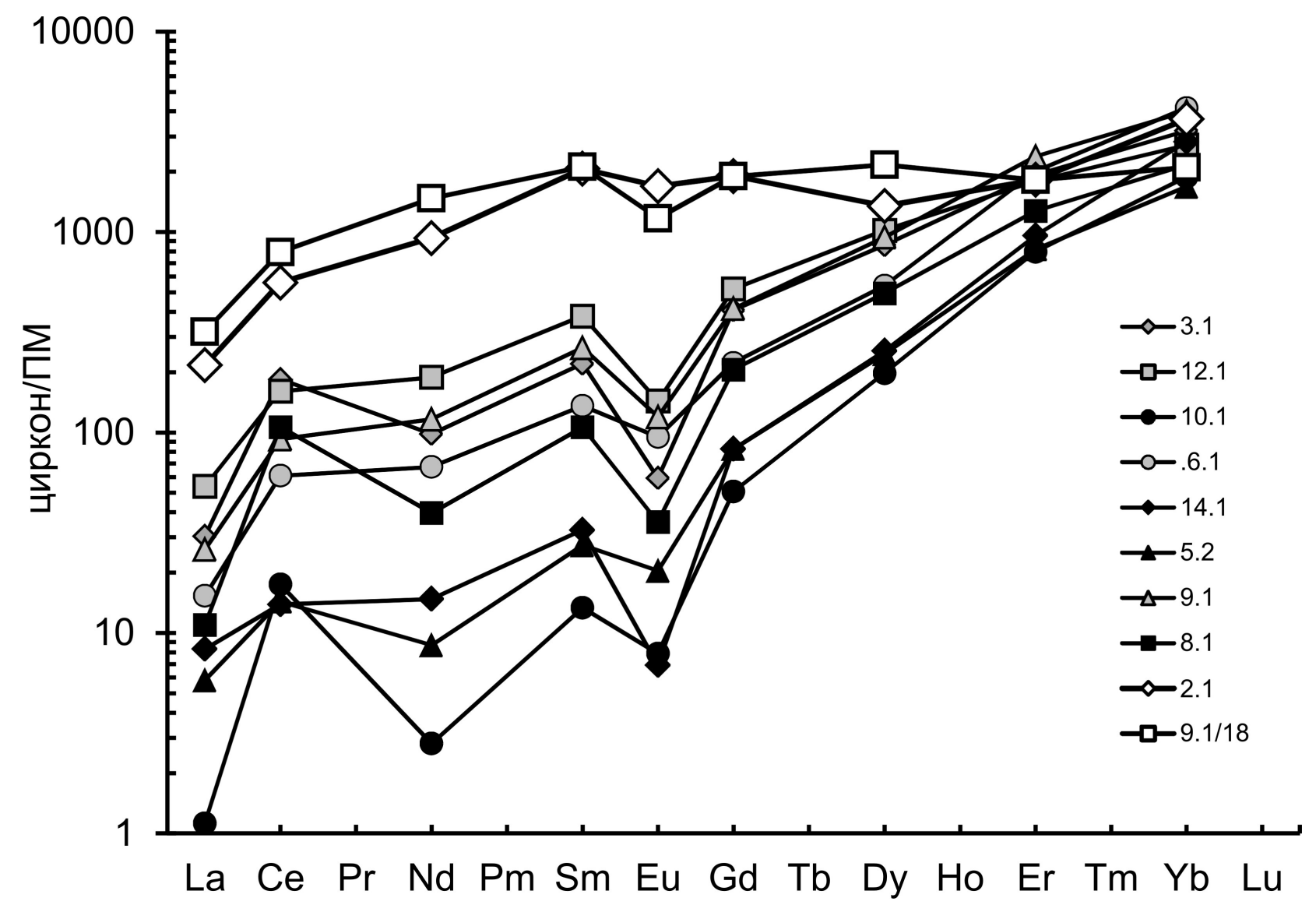



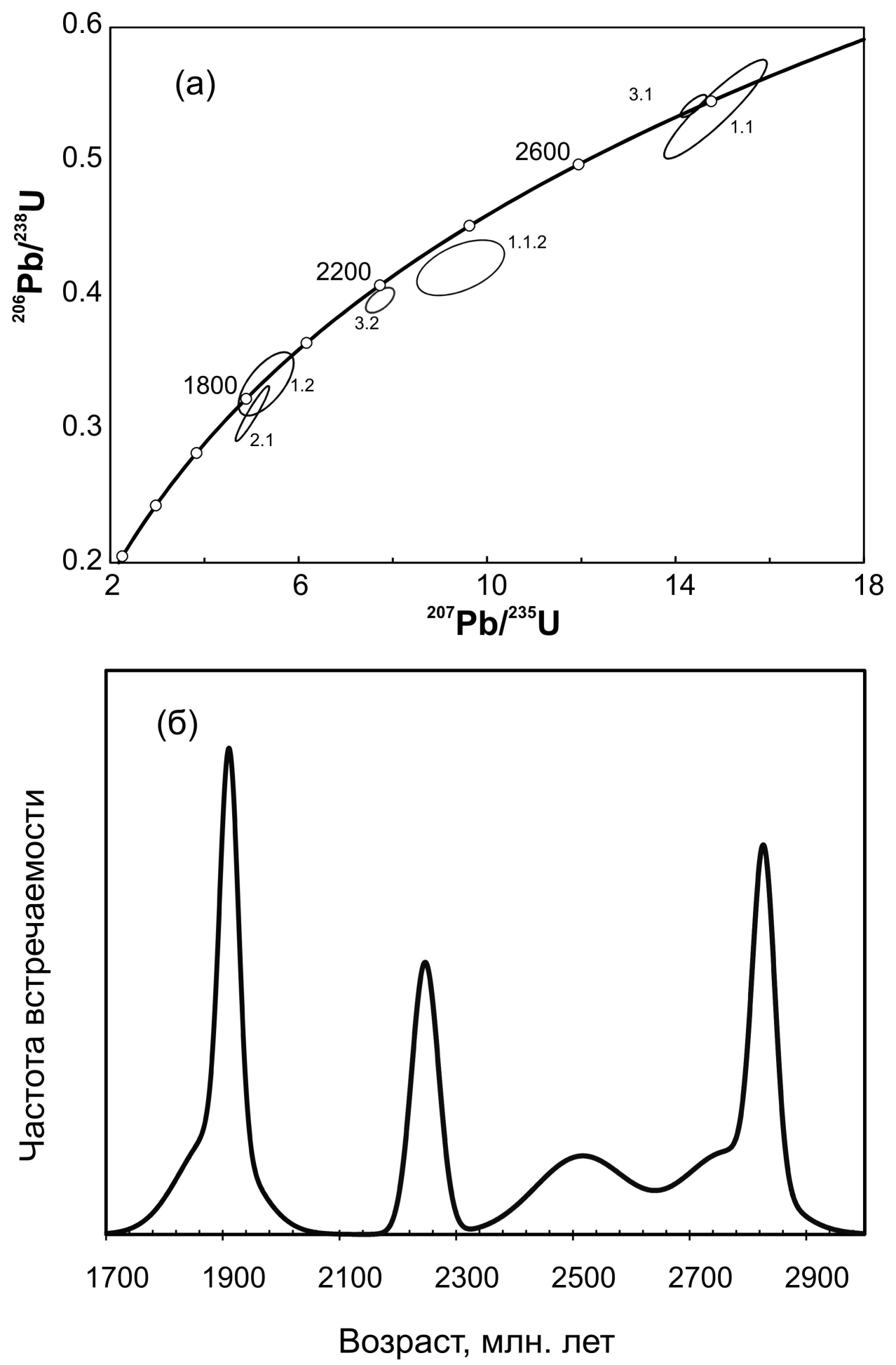

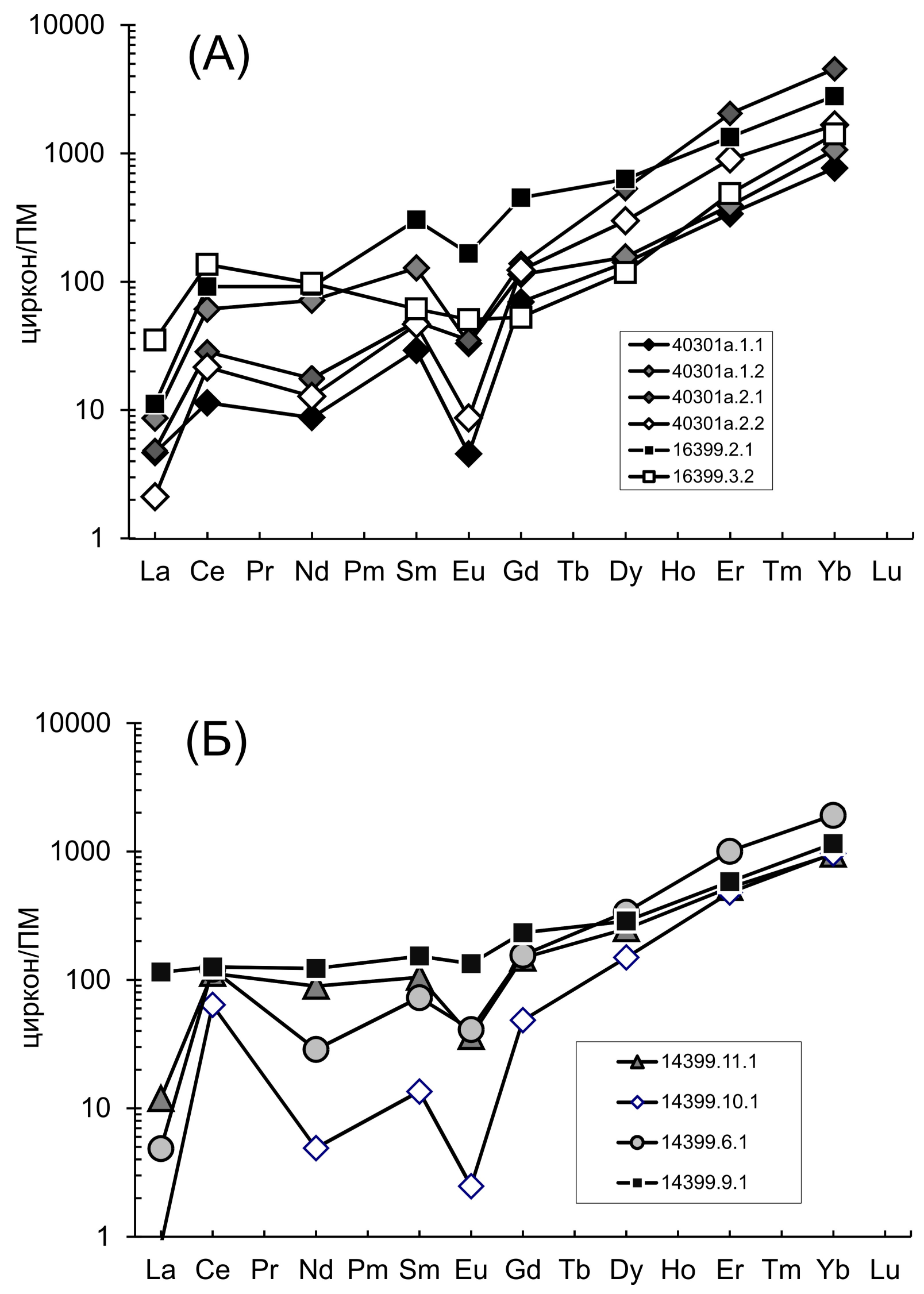

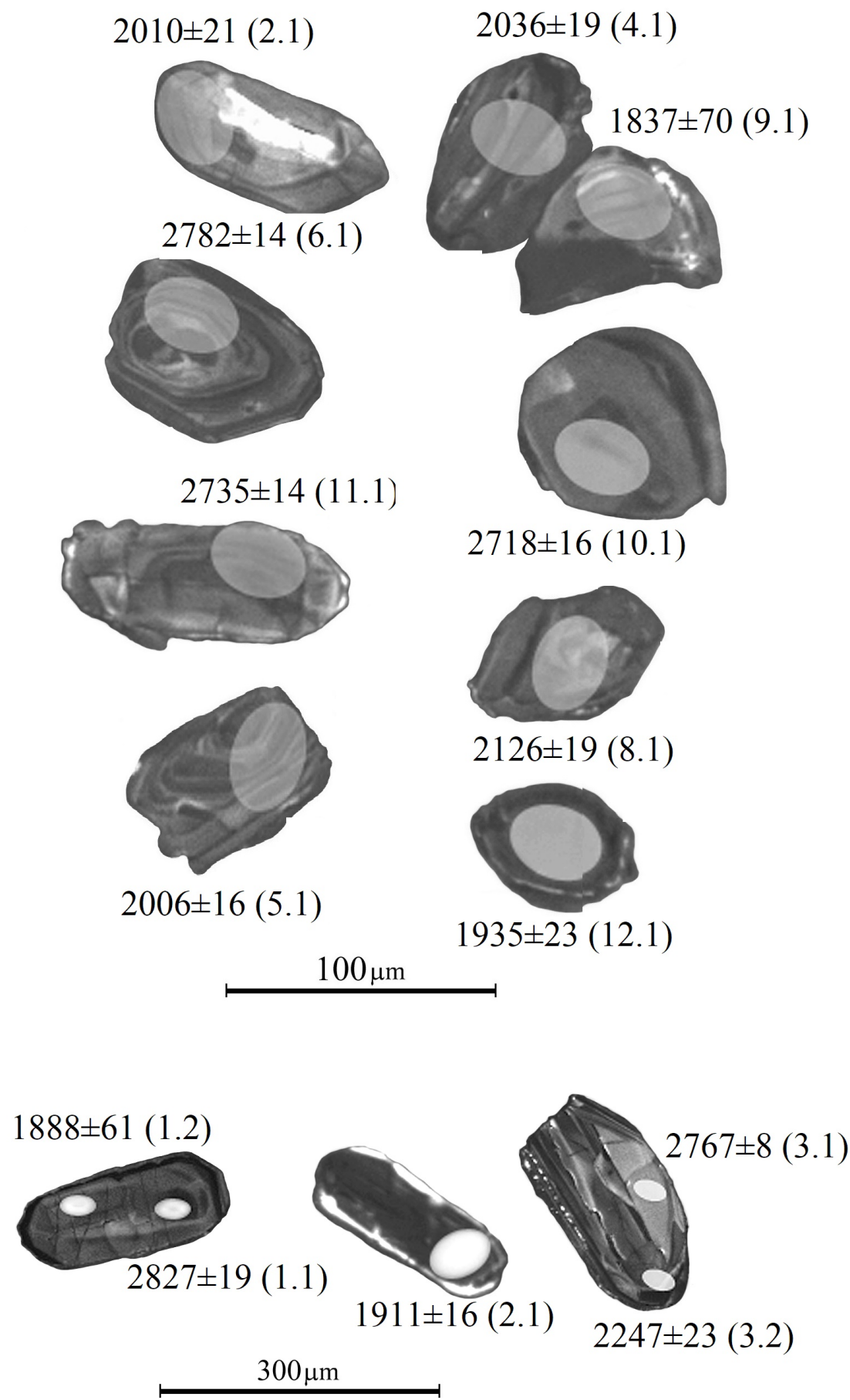

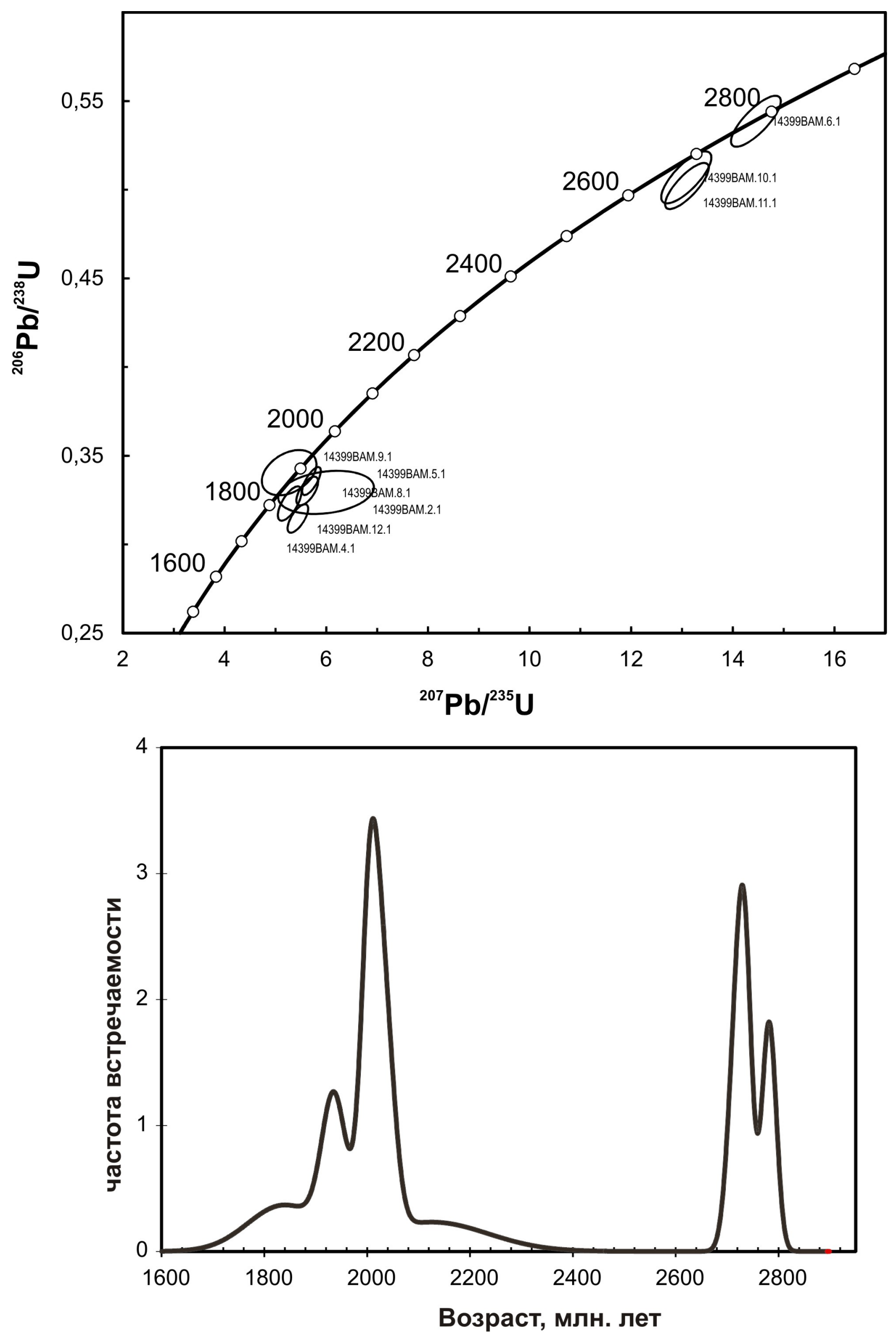